NBER WORKING PAPER SERIES

\title{
THE ORGANIZATION OF FIRMS ACROSS COUNTRIES
}

\author{
Nicholas Bloom \\ Raffaella Sadun \\ John Van Reenen \\ Working Paper 15129 \\ http://www.nber.org/papers/w15129
NATIONAL BUREAU OF ECONOMIC RESEARCH
1050 Massachusetts Avenue
Cambridge, MA 02138
July 2009

Helpful comments on earlier drafts of the paper have come from detailed discussions with Abhijit Banerjee, Bob Gibbons, Avner Greif, Oliver Hart, Bengt Holmstrom, Andrei Shleifer, Julie Wulf, Luigi Zingales and participants at seminars in Duke, the Hague, Harvard, HBS, LBS, Mannheim, MIT, Stanford, Tokyo, UC Merced, USC, Warwick and Wharton. We would like to thank the Economic and Social Research Council, the Anglo-German Foundation, the Advanced Institute for Management and the Kauffman Foundation for their substantial financial support. We received no funding from the global management consultancy firm we worked with in developing the survey tool. Our partnership with Pedro Castro, Stephen Dorgan and John Dowdy has been particularly important in the development of the project. We are very grateful for the endorsement letters from the Banque de France, Bank of Greece, Bank of Japan, Bank of Portugal, Bundesbank, Confederation of Indian Industry, European Central Bank, European Union, Greek Employers Federation, IUI Sweden, Ministero delle Finanze, National Bank of Poland, Peking University, Peoples Bank of China, Polish Treasury, Reserve Bank of India, Shenzhen Development Bank, Sveriges Riksbank, U.K. Treasury and the Warsaw Stock Exchange. 'This paper is part of the SCIFI-GLOW Collaborative Project supported by the European Commission's Seventh Research Framework Programme, Contract number SSH7-CT-2008-217436.' The views expressed herein are those of the author(s) and do not necessarily reflect the views of the National Bureau of Economic Research.

NBER working papers are circulated for discussion and comment purposes. They have not been peerreviewed or been subject to the review by the NBER Board of Directors that accompanies official NBER publications.

(C) 2009 by Nicholas Bloom, Raffaella Sadun, and John Van Reenen. All rights reserved. Short sections of text, not to exceed two paragraphs, may be quoted without explicit permission provided that full credit, including (C) notice, is given to the source. 
The organization of firms across countries

Nicholas Bloom, Raffaella Sadun, and John Van Reenen

NBER Working Paper No. 15129

July 2009

JEL No. L2,M2,O32,O33

\begin{abstract}
$\underline{\text { ABSTRACT }}$
We argue that social capital as proxied by regional trust and the Rule of Law can improve aggregate productivity through facilitating greater firm decentralization. We collect original data on the decentralization of investment, hiring, production and sales decisions from Corporate Head Quarters to local plant managers in almost 4,000 firms in the US, Europe and Asia. We find Anglo-Saxon and Northern European firms are much more decentralized than those from Southern Europe and Asia. Trust and the Rule of Law appear to facilitate delegation by improving co-operation, even when we examine "bilateral trust" between the country of origin and location for affiliates of multinational firms. We show that areas with higher trust and stronger rule of law specialize in industries that rely on decentralization and allow more efficient firms to grow in scale. Furthermore, even for firms of a given size and industry, trust and rule of law are associated with more decentralization which fosters higher returns from information technology (we find IT is complementary with decentralization). Finally, we find that non-hierarchical religions and product market competition are also associated with more decentralization. Together these cultural, legal and economic factors account for four fifths of the cross-country variation in the decentralization of power within firms.
\end{abstract}

Nicholas Bloom

Stanford University

Department of Economics

579 Serra Mall

Stanford, CA 94305-6072

and NBER

nbloom@stanford.edu

Raffaella Sadun

Harvard Business School

Morgan Hall 233

Soldiers Field

Boston, MA 02163

and NBER

rsadun@hbs.edu
John Van Reenen

Department of Economics

London School of Economics

Centre for Economic Performance

Houghton Street

London WC2A 2AE

UNITED KINGDOM

and NBER

j.vanreenen@1se.ac.uk 


\section{INTRODUCTION}

Economists have become increasingly aware of the importance of culture on international performance (e.g. Guiso, Sapienza and Zingales, 2006). One influential line of research argues that social capital as indicated by measures of trust or more widely, by the Rule of Law, fosters faster growth (e.g. Knack and Keefer, 1997 or La Porta, Lopez-de-Silanes, Shleifer and Vishny, 1998). The mechanisms through which this might happen are not fully understood, however. In this paper we present evidence that high social capital in an area increases decentralized decision making within firms. We show that that decentralization favors productivity through supporting a larger equilibrium firm size and is complementary with information technology.

Trust can be seen as a reflection of the congruence of preferences as in Aghion and Tirole (1997), or as a mechanism for obtaining co-operation in relational contracts as in Baker, Gibbons and Murphy (1999). If a CEO can trust his senior managers he will be more willing to decentralize decision making - for example, the threat of theft is lower. Rule of Law should operate though a similar mechanism: there is more chance of getting stolen money back (and also less change of theft in the first place) if contracts are well enforced and respected.

This paper subjects the "organizational” view of social capital to rigorous econometric investigation and concludes that trust is critical to the ability of a firm to decentralize. We show that trust in a region (even after controlling for country dummies) is associated with larger firms and a different pattern of industry specialization, and that even conditional on size and industry, firms in high trust areas are more decentralized.

Countries that find decentralization more costly may suffer lower welfare for several reasons. First, it will be difficult for markets to effectively allow the more efficient firms to grow large. Penrose (1959) and Chandler (1962) argued that decentralization was essential for the creation of large firms, because CEOs are constrained over the number of decisions they can make. As firms grow CEOs need to increasingly decentralize decision making power to their senior management. In our data we find that larger firms are indeed significantly more decentralized. This is important because for capital and labor to be effectively reallocated across firms, productive firms need to grow large and take market share from unproductive firms. This reallocation is a major factor driving growth in 
developed countries like the US. ${ }^{1}$ But in developing countries like India, where firms are typically quite centralized, average firm size is smaller, so that the most productive firms have a smaller market share. ${ }^{2}$ One potential explanation is CEOs in countries like India are less likely to delegate, for example because of the fear of theft by their senior management, constraining the growth of firms. The difficulties faced by firms in developing economies to grow reduces aggregate productivity by limiting the ability of productive firms to expand their market share, thereby reallocating resources away from less productive firms.

Second, economies with low trust will specialize in industries where decentralization is less important. There has been a global trend towards more decentralization which is plausibly related to increasing competition (Guadalupe and Wulf, 2008), the supply of human capital (Caroli and Van Reenen, 2001) and the growth of information technology (Bresnahan, Brynjolffson and Hitt, 2002). In support of the latter idea we present evidence from production functions that information technology is complementary with decentralization ${ }^{3}$. If these trends continue, low trust nations with a comparative disadvantage in decentralization will suffer lower productivity growth than those with greater social capital.

To tackle these issues we need detailed information on the internal organization of firms across nations. The economic theory of organization has made great strides in the last two decades in furthering our understanding of activities within the boundary of the firm ${ }^{4}$, but empirical research on this has lagged far behind because of a lack of organizational data. The few datasets that exist are either from a single industry ${ }^{5}$ or (at best) across many firms in a single country ${ }^{6}$. We address this lacuna by analyzing data on the organization of almost 4,000 firms across twelve countries in

\footnotetext{
${ }^{1}$ See, for example, Foster, Haltiwanger and Krizan (2000 and 2006) who show that about 50\% of productivity growth in manufacturing and about $90 \%$ in retail comes from reallocation.

${ }^{2}$ See, for example, Hsieh and Klenow (2009).

3 Bloom, Garicano, Sadun and Van Reenen (2009) present a model of a cognitive hierarchy where middle level employees (e.g. plant managers) will gain more power relative to the CEO when the cost of information acquisition falls (IT enables them to solve more problems without asking central “experts”).

${ }^{4}$ For a survey see Bolton and Dewatripont (2005) or Gibbons and Roberts (2008). One branch of the literature investigates conditions under which delegated contracting replicates efficient centralized contracting, for example Baron and Besanko (1992) and Melumad et al (1995). However, this required complete contracts (see Mookherjee, 2006). A second branch emphasizes information processing and communication costs such as Sah and Stiglitz (1986), Genakopolos and Milgrom (1991), Radner (1993), Radner and Van Zandt (1992), Bolton and Dewatripont (1994) and Garicano (2000). A third branch, closest to our perspective, emphasizes the trade off between information and loss of control - see Aghion and Tirole (1997), Rajan and Zingales (2001), Dessein (2002), Hart and Moore (2005) and Alonso, Dessein and Matouschek (2008).

${ }^{5}$ See, for example Baker and Hubbard (2003, 2004) on trucks or Garicano and Hubbard (2007) on legal services.

${ }^{6}$ See for example, Acemoglu, Aghion, Lelarge, Van Reenen and Zilibotti (2007) for France and the UK, Colombo and Delmastro (2004) and Kastl, Martimort and Piccolo (2008) for Italy, and Rajan and Wulf (2007) for the US.
} 
Europe, North America and Asia. We designed and collected this data using a new survey tool and measure the decentralization of investment, hiring, production and pricing decisions from the Central Head Quarters (CHQ/CEO) to plant managers. This data reveals startling differences in the cross-country decentralization of firms: those in the US and Northern Europe appears to be the most decentralized and those in Southern Europe and Asia the most centralized.

Empirically, we find that trust and Rule of $\mathrm{Law}^{7}$ are strongly associated with more decentralized firms. Trust is measured at the regional level using individual responses in the World Value Survey, and the positive relationship between trust and decentralization is even true for multinationals by country of origin: in California a multinational affiliate from Sweden (a high trust country) would typically be more decentralized than a multinational affiliate from Portugal (a low trust country). We further show this is driven by bilateral trust which seems to affect not only trade and investment (Guiso, Sapienza and Zingales, 2008), but also the internal organization of multinationals.

Two other factors also stand out in accounting for decentralization: religion and product market competition. Plants in areas with a high share of hierarchical religions ${ }^{8}$ are significantly more centralized, which is potentially due to a lower taste for decision-making authority by local managers ${ }^{9}$. Furthermore, we also find we find that decentralization is positively associated with the degree of product market competition. This may arise because of the greater importance of local knowledge in time sensitive environments or through disciplining effects, reducing the need for central monitoring. Together these cultural, legal and economic factors account for around $80 \%$ of the cross country variation in decentralization.

Apart from the organizational economics and social-capital and development literature, our paper is also related to two other strands of the literature. One is on multinationals and comparative advantage. A recent body of theoretical work, such as Helpman, Melitz and Yeaple (2004), Burstein and Monge (2007) and Antras, Garicano and Rossi-Hansberg (2008) emphasizes the importance of

\footnotetext{
${ }^{7}$ Rule of Law is measure from the World Bank index developed by Kauffman, Kray and Matruzzi (2006), and we find that firms in strong Rule of Law countries tend to be more decentralized even after controls for a range of other countrylevel factors like skills and levels of development.

${ }^{8}$ Our primary definition follows La Porta et al. (1997), who define Catholicism, Eastern Orthodoxy and Islam as hierarchical religions, but we investigate other partitions.

${ }^{9}$ An alternative interpretation is that hierarchical religions reduce trust between people because they inhibit the horizontal bonds between individuals (Putnam, 1993, La Porta et al. 1997, Guiso, Sapienza and Zingales, 2004). However, we still find some role for hierarchical religion even after controlling for its effect in reducing trust, suggesting an additional more direct effect on decentralization.
} 
firm-level comparative advantage in multinationals. In these models firms have some productivity advantage, typically deriving from a different managerial or organizational technology, which their multinationals transplant to their overseas affiliates. Our evidence on the ability of multinationals to take their domestic organizational practices abroad provides empirical support for this assumption.

Second, there is the literature on the transportation of culture by individuals across countries. For example, Fisman and Miguel (2008) show that the parking fine behavior of diplomats in New York is strongly predicted by indices of corruption in their home countries ${ }^{10}$. Our evidence suggests that firms also take part of their "culture” abroad. Interestingly, we find this holds even in multinationals when all the managers come from the country of location, suggesting that firms offer an additional mechanism for transporting culture across countries.

The paper is organized as follows. Section II sketches our models and its empirical implications, Section III details the data and Section IV has some descriptive statistics. The empirical results are split into the basic results in Section V and some extensions in Section VI. Section VI concludes.

\section{THEORETICAL CONSIDERATIONS AND EMPIRICAL IMPLICATIONS}

We first look at theories of decentralization within a given firm holding size constant, and then the joint determination of decentralization and firm size. There is a huge theoretical literature on the determinants of decentralization within organizations and we do not aim to survey this, but instead give a framework for the empirical results which are the focus of the paper.

\section{II.A Trust, Rule of Law and Decentralization}

A number of papers such as Aghion and Tirole (1997), Prendergast (2002), Hart and Moore (2004) and Acemoglu et al (2007) consider the delegation decision in the context of an information-based approach. They motivate their models with a choice that a firm faces, for example over how to use a new technology. The principal is the Central Head Quarters (CHQ) and the agent is the plant

\footnotetext{
${ }^{10}$ In the social domain, Fernandez and Fogli (2007) and Giuliano (2007) show that fertility rates among secondgeneration Americans are correlated with fertility in the countries of their parents. And Ichino and Maggi (2000) study absenteeism and misconduct of employees at an Italian bank, and find that region of origin within Italy predicts shirking.
} 
manager. The CHQ has a greater interest in maximizing the firm's value than the manager, but the manager has greater local private knowledge than the CHQ. This trade-off determines the optimal degree of decentralization. Thus, characteristics of the environment that increases: (i) the value of local information; and (ii) the congruence of incentives between the CHQ and plant manager, will increase decentralization. If trust reflects a greater congruence of preferences between the parties, this should lead to great delegation.

Even if decentralization was the efficient choice due to the characteristics of the firm's environment, Baker, Gibbons and Murphy (1999) emphasize that delegation is generally informal rather than formal because the CHQ must usually sign-off on decisions. The issue is whether the CHQ credibly commits to allowing the plant manager to effectively make the important decisions and does not override the plant manager (in order to establish his reputation not to interfere). Thus, the level of decentralization is the outcome of a repeated game between the CHQ and manager ${ }^{11}$. The agent and principal's preferences and beliefs in these models will of course influence the level of delegation. Trust is emphasized in the social capital and experimental game theory literatures as one factor that leads to co-operation (Putnam, 1993, Fukuyama, 1995; Glaeser, Laibson, Scheinkman and Soutter, 2000). If there are heterogeneous types in the population with some ex ante being more likely to cooperate than others, then the co-operative outcome (decentralization) is more likely.

In principle, an alternative to trust in sustaining co-operation is Rule of Law. When the employer (or employee) can successfully sue for breach of contract this will make contracts easier to enforce and sustainable delegation more likely. This will be particularly important in larger firms (Greif 1993). So throughout our main analysis we will consider the independent influence of Rule of Law (“LAW”) alongside trust.

Based on these theoretical considerations our main econometric model of decentralization takes the following form:

$$
D_{i j c k}=\beta_{1} \operatorname{TRUST}_{j c}+\beta_{2} L A W_{c}+\delta^{\prime} x_{i j k c}+u_{i j k c}
$$

Where the outcome of interest is the degree of decentralization of plant $i$ in region $j$ in industry $k$ in country $c\left(D_{i j c k}\right)$. This is modeled as a function of four variables of interest: trust in the region $j$ in

${ }^{11}$ Other models, like Rajan and Zingales (2001) focus on the intangible capital view of the firm, with ownership being structured so that employees cannot easily split off easily to create rival firms. 
country $c$ where the plant is located (TRUST $T_{j c}$ ) and Rule of Law in the country where the plant is located $\left(L A W_{c}\right)$. We also include a vector of control variables, $x_{i j k c}$ and an error term, $u_{i j k c}$. The controls include skills, multinational status, listing status, regional GDP per head, regional population and three digit industry dummies. When we include country dummies (as we do in most of our specifications) we cannot separately identify Rule of Law. We also construct a large number of other controls for the measurement error in $D_{i j c k}$ including interviewer fixed effects and controls for the characteristics of the interview and interviewee (see data section). We consider specifications with and without controlling for firm size as discussed next.

\section{II.B Endogenizing Firm size}

The early literature on firm size focused on the issue of decentralization, arguing this was essential for creating large firms due to the time constraint on the number of decisions a CEO can take. Penrose (1959) developed the "resource based" view of the firm, claiming that managerial capacity was a key resource in determining firm size. If senior management time - and in particular CEO time - could be leveraged across a larger group of middle managers, then firm size could be increased.

Chandler (1962) examined the growth of large modern multi-divisional firms in the US after the 1850s. He argued that these larger firms were created through setting up "local field units”, which were regional factories or sales-outlets, with decentralized decision making power from the CHQ. Again, decentralization was necessary to allow distant units to operate, since limits on communication meant that the CHQ can never hope to direct managers operating hundreds of miles away. Without decentralization these firms would have not been able to grow.

What naturally arises from this literature is the prediction that factors which facilitate decentralization, such as greater trust will encourage the creation of larger firms. This could then play a key role in increasing aggregate productivity through enabling more productive firms to increase their size and market share.

One way to illustrate the impact of decentralization on firm size and aggregate productivity is through the Lucas (1978) model of firm size. In the Lucas model individuals have a spread of managerial talent, denoted $x$. High ability individuals (above some cut-off $x^{*}$ ) act as managers and 
all other individuals (those with ability below $x^{*}$ ) work for them as employees. Managerial ability can be leveraged across many employees, but with a diminishing return. A manager of ability $x$ managing a firm with $n$ employees and $k$ capital produces output of $x g(f(n, k))$, where $f($.$) is a$ standard production function, and $g\left(\right.$.) is the managerial control function where $g^{\prime}()>$.0 and $g$ '”(.)<0. The decreasing returns in $g$ (.) comes from the assumption of a finite span of control for managers, arising from their limited managerial supply of time. Increasing the ability of managers to effectively decentralize decisions in the Lucas (1978) model would be represented by a reduction in the concavity of $g\left(\right.$.). For example, if $g$ (.) were a Cobb-Douglas production function, $g(z)=z^{\alpha}$, where $0<\alpha<1$, this would be equivalent to increasing $\alpha$. The impact of this would be to increase average productivity by raising the number of workers employed by the best managers. Simultaneously, it would increase the average firm size as the lower quality managers become workers (the ability threshold $x^{*}$ would increase) reducing the number of firms. The predictions of this are that: (i) trust should be associated with higher aggregate productivity, which the social capital literature discussed in section (IA) provides prior empirical support for; and (ii) that firm size should be positively linked with trust. $^{12}$

\section{II.C Religion and competition}

A long literature since Weber (1930) argues that religious practices and beliefs have important consequence for economic growth (see also Barro and McCleary, 2006). A recent literature ${ }^{13}$ explores one dimension of this, arguing that hierarchical religions such as Catholicism reduce trust by inhibiting the formation of horizontal relations between people in favor of vertical relations with the Church. Religion may also have a direct link to decentralization, over and above its influence on trust, due to its association with preferences for autonomy. To see why, consider the idea that individuals have different tastes for autonomy - i.e. some people want to make their own decisions (rather than being told to do by their boss) more than others. This taste parameter varies in the population, so that when individuals in certain regions have a stronger taste for autonomy there is more likely to be decentralization. This variation in the taste for autonomy may be linked with the

\footnotetext{
${ }^{12}$ Related to this is La Porta et al. (1997) who found in cross-country regressions that the combined size of the largest 25 public quoted firms was positively correlated to trust and the Rule of Law. Kumar, Rajan and Zingales (2003) also looked across countries, again finding the average size of enterprises was significantly correlated with Rule of Law. Laevan and Woodruff (2007) looked at the impact of rule of law on firm size across regions within Mexico, finding larger firms where rule of law is better. We extend this work by: (i) looking at variations of trust within countries; and (ii) using the population of all firms which allows us to control for differences in coverage, listing, industry and enterprise definition across countries.

${ }^{13}$ See, for example, Putnam 1993, La Porta et al. 1997 and Guiso et al. 2004.
} 
prevalence of hierarchical religions, defined as Catholicism, Eastern Orthodox and Islam following La Porta et al (1997). This could be because the success of these religions in different areas depended on their inhabitants' preferences, so religious affiliations proxy for some deeper underlying cultural differences in tastes for autonomy. Alternatively, the presence of hierarchical religions could directly cause variations in the taste for autonomy, if it conditions individuals to be more accepting of authority from an early age ${ }^{14}$.

A final aspect we focus on is product market competition, which is also likely to affect decentralization for several reasons (see Guadalupe and Wulf, 2009, for a more extensive discussion and survey). First, more competitive environments put a greater emphasis on the rapid reaction to events because of a greater sensitivity of relative profitability to relative differences in marginal costs/quality between firms. In these circumstances, delegating to managers with local information will be particularly beneficial. Secondly, if competition is associated with an increased number of firms it makes yardstick competition easier to implement and therefore enables the CHQ to combine decentralization with increased managerial effort. Finally, if competition increases the threat of bankruptcy then the manager is more likely to make the firm's value maximizing decision if the CHQ delegates. This makes the likelihood of decentralization greater when competition is tougher, although there are counterarguments. For example, more firms means more public knowledge so there is less need to delegate to privately knowledgeable managers. Consequently, the effect of competition on decentralization is ultimately an empirical issue.

Our most general specification is therefore:

$$
D_{i j c k}=\beta_{1} \operatorname{TRUST}_{j c}+\beta_{2} L A W_{c}+\beta_{3} \operatorname{HIER}_{j c}+\beta_{4} P M C_{i k c}+\beta_{5} S I Z E_{i j k c}+\delta^{\prime} x_{i j k c}+u_{i j k c}
$$

Where HIER denotes the proportion of people in a hierarchical religion in the plant's region and $P M C$ is an indicator of product market competition. Unfortunately, many of the interesting structural characteristics of the industry such as its heterogeneity and technological complexity are not separately identified from industry dummies, so we cannot examine them in detail here (see Acemoglu et al, 2007).

${ }^{14}$ Guiso et al (2003) argue for a causal effect of religion noting that Catholics growing up after Vatican II were more liberal than a control group. 


\section{DATA}

To investigate these theories we first have to construct a robust measure of organizational practices overcoming four hurdles: measuring decentralization, collecting accurate responses, ensuring international comparability and obtaining interviews with managers. We discuss these in turn.

\section{III.A Measuring Decentralization}

We asked four questions on plant manager decentralization. First, we asked how much capital investment a plant manager could undertake without prior authorization from the corporate headquarters (CHQ). This is a continuous variable enumerated in national currency which we convert into dollars using PPPs. We also inquired on where decisions were effectively made in three other dimensions: (a) hiring a new full-time permanent shopfloor employee, (b) the introduction of a new product and (c) sales and marketing decisions. These more qualitative variables were scaled from a score of 1 , defined as all decisions taken at the corporate headquarters, to a 5 defined as complete power ("real authority") of the plant manager. In Appendix Table A1 we detail the individual questions in the same order as they appeared in the survey.

Some of these four questions are similar to others used in the past to measure decentralization. Acemoglu et al (2007) use a similar question on hiring in the British WERS data and Columbo and Delmastro (2004) have a question similar to our one on investment for Italian establishments ${ }^{15}$.

Since the scaling may vary across all these questions, we converted the scores from the four decentralization questions to z-scores by normalizing each one to mean zero and standard deviation one. In our main econometric specifications, we take the un-weighted average across all four zscores as our primary measure of overall decentralization, but we also experiment with other weighting schemes and also the individual questions.

One issue is over measurement of decentralization across different organizational structures. Figure 1 provides four examples to help explain how we did this. Example A shows the classic case, where the firm has one CHQ in New York and one production site in Phoenix. The plant manager is defined as the most senior manager at the Phoenix site, with our decentralization measure evaluating

${ }^{15}$ Marin and Verdier (2007) use a count of a series of decentralization variables scaled between 1 and 5 in German and Austrian firms. 
how much autonomy he has from his manager in New York. In Example B we depict a firm with multiple plants, in which we would usually survey one plant and assumed this represented the degree of decentralization for the firm (section III.F discusses how we test this assumption). In Example C we have a firm with the production facilities and CHQ on the same site. In this case if the plant manager was the CEO - which occurred in $4.9 \%$ of our interviews - we could not define decentralization (so these observations were dropped). ${ }^{16}$ If the plant manager and CEO were different people on the same site we would define decentralization as usual, but we also confirm in Appendix A that our results are robust to dropping these "same-site" observations. ${ }^{17}$ Finally, in Example D we show a multinational subsidiary, which we treat the same as domestic firms, defining decentralization as the autonomy of the plant from the domestic CHQ. Again, we also confirm robustness of our results to dropping these multinational subsidiaries ${ }^{18}$.

Finally, we collected a large amount of additional data from the survey to use as controls: management practice information following the methodology of Bloom and Van Reenen (2007); proportion of the workforce with degrees, average hours worked and the gender and age breakdown. We also collected ownership information from the managers, which we cross-checked against the external sample databases (see section III.E for details). From the sample database we also have information for most firms on their basic accounting variables like sales and capital stock.

\section{III.B Collecting Accurate Responses}

An important issue on our survey methodology is the extent to which we can obtain unbiased responses to our questions. In order to achieve this we took a range of steps to obtain accurate data. First, the survey was conducted by telephone without telling the managers they were being scored on organizational or management practices. This enabled scoring to be based on the interviewer's evaluation of the firm's actual practices, rather than their aspirations, the manager's perceptions or the interviewer's impressions. To run this "blind" scoring we used open questions (i.e. "To hire a

\footnotetext{
${ }^{16}$ These were typically smaller firms (a mean firm employment of 159 for the CEO plant manager firms versus 843 for the rest of the sample), with an insignificant correlation between the share of firms dropped in each country and its average decentralization measure. The country level correlation was 0.345 (p-value of 0.272 ).

17 Empirically, while plant managers with CEOs on site typically have less autonomy (something we control for empirically) it is not the case they have no autonomy. The CEO will typically be involved in a number of other tasks such as finance, strategy and sales (which could involve other non-production sites), while the plant manager runs the daily production process. An example in a university context would be a Dean of Humanities and the Head of the Economics Department - they are both on the same site, but the Head of Department still has some autonomy.

${ }^{18}$ We also asked two questions on decentralization from plant managers to workers over their allocation of tasks across teams and the determination of pace on the shop-floor (see Bloom et al, 2009).
} 
full-time permanent shop-floor worker what agreement would your plant need from corporate headquarters”?), rather than closed questions (i.e. “Can you hire workers without authority from corporate headquarters?"[yes/no]). Following the initial question the discussion would continue until the interviewer can make an accurate assessment of the firm's typical practices. For example, if the plant manager responded "It is my decision, but I need sign-off from corporate HQ." the interviewer would ask "How often would sign-off typically be given?" with the response "So far it has never been refused" scoring a 4 and the response "Typically agreed in about $80 \%$ of the case" scoring a 3.

Second, the interviewers did not know anything about the firm's financial information or performance in advance of the interview. This was achieved by selecting medium sized manufacturing firms and by providing only firm names and contact details to the interviewers (but no financial details). Consequently, the survey tool is "double blind" - managers do not know they are being scored and interviewers do not know the performance of the firm. The interviewers were incentivized on the number of interviews they ran and so had no interest in spending time researching the companies in advance of running the interview. These manufacturing firms (the median size was 270 employees) are too small to attract much coverage from the business media. All interviews were conducted in the manager's native language.

Third, each interviewer ran 85 interviews on average, allowing us to remove interviewer fixed effects from all empirical specifications. This helps to address concerns over inconsistent interpretation of categorical responses, standardizing the scoring system. Fourth, the survey instrument was targeted at plant managers, who are typically senior enough to have an overview of organizational practices but not so senior as to be detached from day-to-day operations.

Fifth, we collected a detailed set of information on the interview process itself (number and type of prior contacts before obtaining the interviews, duration, local time-of-day, date and day-of-the week), on the manager (gender, seniority, nationality, company and job tenure, internal and external employment experience, and location), and on the interviewer (we can include individual interviewer-fixed effects, time-of-day and subjective reliability score). These survey metrics are used as “noise controls” to help reduce residual variation. 


\section{III.C Ensuring International Comparability}

In comparing organizational and management surveys across countries we have to be extremely careful to ensure comparability of responses. To maximize comparability we undertook three steps. First, every interviewer had the same initial three days of interview training, provided jointly by the Centre for Economic Performance (CEP) at the London School of Economics (LSE) and our partnering international consultancy firm. This training included three role-play calibration exercises, where the group would all score a role-played interview and then discuss scoring together of each question. This was aimed at ensuring every interviewer had a common interpretation of the scoring grid. In addition every Friday afternoon throughout the survey period the group met for 90 minutes for training and to discuss any problems with interpretation of the survey.

Second, the team operated from one location, the LSE. The different national survey teams were thus organized and managed in the same way, ran the surveys using exactly the same telephone, computer and software technology and were able to directly discuss any interpretation issues. ${ }^{19}$ Third, the individual interviewers interviewed firms in multiple countries. The team language was English, so that interviewers were able to interview firms from their own country plus the UK and US. As a result the median number of countries that each interviewer scored firms in was three, enabling us to remove interviewer fixed effects in the cross-country analysis.

\section{III.D Obtaining Interviews with Managers}

Each interview took on average 48 minutes and was run in the Summer of 2006. Overall, we obtained a relatively high response rate of $45 \%$, which was achieved through four steps. First, the interview was introduced as "a piece of work" ${ }^{20}$ without discussion of the firm’s financial position or its company accounts. Interviewers did not discuss financials in the interviews, both to maximize the participation of firms and to ensure our interviewers were truly "blind" on the firm's financial position. Second, the survey was ordered to lead with the least controversial questions on (shop-floor operations management), leading on to monitoring, incentives and organizational structure. Third, interviewers' performance was monitored, as was the proportion of interviews achieved, so they were persistent in chasing firms. ${ }^{21}$ Fourth, the written endorsement of many official institutions ${ }^{22}$

\footnotetext{
${ }^{19}$ See http://www.youtube.com/watch?v=HgJXt8KwhA8 for video footage of the survey team.

${ }^{20}$ We avoided using the words "research" or "survey" as many firms link these to market research surveys.

${ }^{21}$ We found no significant correlation between the number, type and time-span of contacts before an interview is conducted and the management score.
} 
helped demonstrate to managers this was an important academic exercise with official support. Fifth, we hired high quality (mainly MBA student) interviewers ${ }^{23}$, mostly with prior manufacturing experience, which helped to signal to managers the high quality nature of the interview.

\section{III.E Sampling Frame and Additional Data}

Since our aim is to compare across countries we decided to focus on the manufacturing sector where productivity is easier to measure than in the non-manufacturing sector. We also focused on medium sized firms, selecting a sample of firms with between 100 and 5,000 workers (with a median of 270). Very small firms have little publicly available data. Very large firms are likely to be more heterogeneous across plants. We drew a sampling frame from each country to be representative of medium sized manufacturing firms and then randomly chose the order of which firms to contact (see Appendix B for details). Since we use different databases in Europe (Amadeus), the U.S. (Icarus), China and Japan (Oriana) and India (Firstsource) we had concerns regarding the cross-country comparisons so we include country dummies in most of the specifications. Comparing responding firms with those in the sampling frame, we found no evidence that the responders were systematically different on any of the performance measures to the non-responders. They were also statistically similar on all the other observables in our dataset. The only exception was on size and multinational status, where our firms were slightly larger and more likely to be multinational than those in the sampling frame (details in Data Appendix).

\section{III.F Evaluating and Controlling for Measurement Error}

The data potentially suffers from several types of measurement error. To quantify this we performed repeat interviews on 72 firms, contacting different managers in different plants at the same firm, using different interviewers. To the extent that our organizational measure is truly picking up company-wide practices these two scores should be correlated, while to the extent the measure is driven by noise the measures should be independent. The correlation of the first interview against the second interviews was 0.513 (p-value of 0.000). Furthermore, there is no obvious (or statistically significant) relationship between the degree of measurement error and the decentralization score.

22 The Banque de France, Bank of Greece, Bank of Japan, Bank of Portugal, Beijing University, Bundesbank, Confederation of Indian Industry, European Central Bank, European Commission, Greek Employers Federation, IUI Sweden, Ministero delle Finanze, National Bank of Poland, Peoples Bank of China, Polish Treasury, Reserve Bank of India, Shenzhen Development Bank, Sveriges Riksbank, U.K. Treasury and Warsaw Stock Exchange

${ }^{23}$ Interviewers all post-graduate students drawn from the following universities: Berkeley, City of London, Columbia, Harvard, HEC, IESE, Imperial, Insead, Kellogg, LBS, LSE, Lund, MIT, Nova de Lisbon, Oxford, Stanford and Yale. 
That is to say, firms that reported very low or high decentralization scores appeared to be genuinely very centralized or decentralized, rather than extreme draws of sampling measurement error.

\section{III.G Trust and Hierarchical Religions}

We build trust measures using the World Values Survey (WVS), a collection of surveys administered to representative samples of individuals in 66 countries between 1981 and 2004. These questionnaires contain information on several social, religious and political attitudes. The World Values Survey aims at measuring generalized trust, namely the expectation of the respondent regarding the trustworthiness of other individuals. The wording of this question is "Generally speaking, would you say that most people can be trusted, or that you can't be too careful in dealing with people?". The variable that we use in the econometric regression is the percentage of people choosing the first option in the trust question within the region where the plant is located.

This is the most common measure of trust used in the literature, and appears to be correlated with trusting and/or trustworthy behavior. Glaeser et al (2000), for example, ran a series of experiments using Harvard undergraduate students to see if individual subject's answers to the WVS trust questions are correlated with their trusting or trustworthy behavior. They find significance evidence that this WVS trust question is significantly correlated with the trustworthiness of subjects, even though they are not very good at predicting trusting behavior. They conclude that "While attitudinal trust surveys at best weakly predict any individual's level of trust, they may be good at predicting the overall level of trustworthiness in society". Sapienza et al. (2007) run another series of experiments using Chicago MBA students and find again this WVS question is correlated with individual behavior, although in their case significantly more with trusting behavior rather than trustworthiness. Since we are using these answers grouped to the level of the community as a whole, it is exactly the "society level" variation that we are using, so these papers are reassuring that this WVS trust question does appear to pick up variation in trust.

Figure 2a plots the trust by country and its regional dispersion. In order to exploit this within country variation for identification, we allocate each plant to a well specified geographical region, and use the relevant WVS aggregate for our analysis ${ }^{24}$.

\footnotetext{
${ }^{24}$ The level of aggregation of the WVS variables is dictated by the level of regional detail provided in the survey which varies somewhat across countries. For example, in the US, China and India a region is a group of states, while in Europe a region is narrower coinciding with a NUTS2 or NUTS3 region. To correct for these cross country differences in the
} 
We also use the World Values Survey also to measure the relative importance of different religions in the country or region of interest, using the information provided on the religious denominations of the respondents. Following La Porta et al (1997), the main variable of interest HIER is the percentage of the population belonging to a "hierarchical religion", defined as Catholic, Islamic or

Eastern Orthodox ${ }^{25}$. Figure $2 \mathrm{~b}$ plots the country average of HIER and its regional dispersion. The correlation between HIER and Trust is -0.67 , significant at the $1 \%$ level.

\section{DESCRIPTIVE STATISTICS}

\section{A Decentralization}

Our preferred measure of decentralization is an average across four z-scored measures of plant manager autonomy on hiring, capital expenditure, marketing and product innovations. The resulting variable is what we define as decentralization (or autonomy of the plant manager).

The cross country averages of decentralization are shown in Figure 3, revealing some interesting patterns. Firms located in Asia (China, Japan and India) tend to be much more centralized than firms located in Anglo-Saxon (Germany, UK and US) and Scandinavian (Sweden) countries. The rest of Europe tends to be in the middle of the decentralization ranking - with the exception of firms located in Greece, which appear to be very centralized. The differences between the three groups of countries are statistically significant at the $1 \%$ level, even when we include a full set of firm characteristics and survey noise controls. Table A2 in Appendix provides more details behind these cross-country comparisons and reveals that, while Sweden, the UK and the US are at the top of the decentralization distribution across all four dimensions, for the rest of the countries the ranking varies. For example, Germany tends to be closer to the other Continental European countries included in our sample (i.e. less decentralized) with regards to the hiring and firing autonomy of the plant manager. On the other hand, plant managers working in Japan have limited autonomy because

regional definition, we weight each regression by the ratio of the number of respondents in the region and the overall number of respondents in the country. Weighting by total number of respondents gives similar results, but this gives larger weight to the countries where the WVS covers more individuals. See Appendix B for details.

${ }^{25}$ Since Sunni Muslims do not have the same type of hierarchical religious structure and orthodoxy as Catholicism and Christian Orthodoxy (see Allen, 1995) the inclusion of Islam in the HIER variable may be disputed. To address this concern we also experiment with an alternative version of the HIER variable that excludes Islam. This leaves our main results virtually unchanged. 
hiring is very centralized due to lifetime tenure. Japanese firms do provide more autonomy over capital expenditures and Japanese workers also have high levels of autonomy.

Figure 4 shows the distribution of the decentralization variable across countries. It is clear that there is a huge amount of heterogeneity, even within countries. About $15 \%$ of the overall variance in our decentralization measure is across countries, $8 \%$ is across SIC 3-digit industry class, and $81 \%$ of the variation is orthogonal to both country and SIC 3-digit industry.

\section{IV.B External Validation}

A possible concern is that the cross country differences in decentralization emerging from our study may reflect the specific characteristics of the firms which participated in the survey (i.e. medium sized manufacturing firms), rather than more general organizational features. Therefore, to validate our decentralization measure, we compared it to two other cross-country decentralization indices that exist in the literature.

The first is the Power Distance rankings created by Hofstede (2001). The Power Distance Index (PDI) is a measure of interpersonal power or influence between a boss and its subordinate, built out of successive attitudinal surveys conducted on more than 70,000 IBM employees across approximately 50 countries in the 1970s and 1980s. Where our decentralization variable provides a factual description of the average autonomy allocated to the plant-managers, the PDI measures the perceptions of and the preferences for hierarchical among non-managerial IBM employees. The PDI measure is based on aggregating questions relating to: (i) non-managerial employees' perception that employees are afraid to disagree with their managers; (ii) subordinates' perception that their boss tends to take decisions in an autocratic or paternalistic way; and (iii) Subordinates' preference for anything but a consultative style of decision making. High PDI values reflect perceptions of and preferences for self-determination. Figure 5 shows that the country level averages of the PDI and our decentralization measure are extremely similar (correlation 0.80 , significant at the $1 \%$ level). This is reassuring since it suggests that across countries our decentralization variable captures long-lived organizational traits across countries, rather than specific characteristics of our firm sample.

The second cross-country decentralization indices are those created by Arzaghi and Henderson (2005) to evaluate fiscal decentralization across countries. They generated an index on a 0 to 4 scale that averaged over scores for decentralization of Government structure (unitary versus federal) and 
the degree of autonomy and democratization of state, province and municipal governments over taxation, education, infrastructure and policing. A value of 0 denotes the country is fully centralized across every dimension, while a value of 4 denotes a highly decentralized fiscal structure. This measure was calculated for every country with 10 million or more employees in 1995, which includes ten of our twelve countries. Figure 6 shows this fiscal decentralization index is also extremely close to our decentralization index (correlation of 0.827 , significant at the $1 \%$ level). Thus, countries in our sample with decentralized firms also tend to have decentralized governments suggesting this is a more general phenomenon.

\section{SOCIAL CAPITAL AND DECENTRALIZATION}

\section{V.A Trust and Decentralization}

\section{Main Results}

As discussed in Section III, incentives to delegate are likely to be diminished in low trust environments. Column (1) of Table 1 presents the results of regressing our decentralization measure against average trust in the region of the country where the plant is located, with no other controls. The relationship between decentralization and trust is positive and highly significant (coefficient 1.115, standard error 0.437). A possible concern is that high levels of trust could simply proxy for better law enforcement, which in turn may facilitate decentralization even in low trust areas. Therefore, in column (2) we include "Rule of Law"26 that enters with a positive and significant coefficient and reduces the coefficient on trust from 1.196 to 0.857 . This suggests that Rule of Law is likely to play a role in encouraging decentralization directly, but that trust also plays an independent role since it remains significant at the $1 \%$ level. ${ }^{27}$ Trust may be associated with decentralization because it sustains larger equilibrium organizational size. Consistent with this mechanism, column (3) shows that larger firms and plants tend to be more decentralized.

\footnotetext{
${ }^{26}$ This indicator was developed by the World Bank and measures "the extent to which agents have confidence in and abide by the rules of society, and in particular the quality of contract enforcement, the police, and the courts, as well as the likelihood of crime and violence” (Kaufmann et al, 2007).

${ }^{27}$ Interestingly, we also find that decentralization regressed on family management (and nothing else) is negative and significant (coefficient of -0.194, standard error of 0.039). If we also include trust and Rule of Law these are highly significant and the family management variable becomes insignificant (coefficient of -0.042 and standard error of 0.030). This suggests that family managed firms are more hierarchical, but potentially because they are formed in areas of low trust and weak rule of law where family ownership is a response to the inability to separate ownership and control.
} 
Conditioning on size reduces the coefficient on trust, but it remains positive and significant, suggesting that even for firms of a given size, trust facilitates decentralization.

Country level indices such as Rule of Law are problematic because they could be correlated with many omitted unobserved country-level factors like regulation (Aghion, Algan, Cahuc and Shleifer, 2008). In column (4) we include country level fixed effects to control for these, so that the trust coefficient is identified only from variation across regions within a country. We also control for regional-level observables (GDP per capita and population) and a general set of firm controls. We find that the coefficient on trust falls slightly to 0.699 , but remains positive and significant at the $5 \%$ level.

In terms of our key covariates in column (4) we find larger firms tend to be more decentralized. This is consistent with the predictions of Alfred Chandler and Edith Penrose, that because CEOs have limited management time, they will delegate more in larger firms. We also find that foreign multinationals are more decentralized relative to both home country multinationals and purely domestic firms. This could again reflect overall firm-size and the larger information gap over greater distances as Chandler emphasized. Finally, more skilled firms are more likely to be decentralized ${ }^{28}$.

We checked whether the trust result may simply capture more general social capital effects. We included "CIVIC", a variable constructed from the World Value Survey and widely adopted in the Social Capital literature ${ }^{29}$, with higher values signifying a higher leniency towards "uncivil” behaviors. The coefficient on CIVIC was insignificant, and left the coefficient on trust practically unchanged.

The magnitude of the association between decentralization and trust is large. For example, moving from the lowest trust region (Assam in India) to the highest trust region (Norrland in Sweden) would be associated with an increase of the decentralization index of 0.44 of a standard deviation. ${ }^{30}$

\footnotetext{
${ }^{28}$ The results are unchanged when we include measures of regional skills, which is positive but insignificant.

${ }^{29}$ Respondents were asked to assign a score between one and ten as to whether they agreed that certain behaviors were justified, with a one indicating the behavior was never justified and a ten indicating that the behavior was always justified. The five behaviors are (1) claiming a government benefit to which you are not entitled, (2) avoiding a fare on public transport, (3) cheating on taxes if you have the chance, (4) buying something that you knew was stolen and (5) accepting a bribe in the course of one's duties. The CIVIC variable is the sum across the five different questions and may range between 5 and 50. The average value of CIVIC in the regression sample is 9.60, and the correlation of the variable with trust is -0.56 , significant at the $1 \%$ level.

${ }^{30}$ Using the 0.699 coefficient in column (4) and the trust values in Assam and Norrland of 0.13 and 0.76 respectively.
} 


\section{Multinationals}

Our sample includes a substantial number of multinational subsidiaries. Looking more closely at the multinational subsidiaries is interesting for two reasons. First, we are interested in whether characteristics (like trust) in the multinational's country of origin have an association with the organizational structure in the multinational's foreign affiliate. This has long been a pre-occupation of business case studies, and the more recent trade literature on the organization of multinationals. ${ }^{31}$ Second, we can include regional fixed effects when conducting this type of analysis, thereby removing any bias associated with other regional characteristics correlated with local trust that could be driving decentralization ${ }^{32}$.

The key hypothesis that we want to study is whether the organization of these types of plants is influenced by the level of trust prevailing in their country of origin (i.e. where the headquarters of the multinationals are located). The results of this analysis are shown in Table 2. These regressions are based on the specification of column (3) in Table 1, where we test the relationship between decentralization and trust (measured in the region of the plant's location), except with two digit rather than three digit industry controls because of the smaller multinational sample. Column (1) shows that in the full sample, the coefficient on trust remains positive and significant (0.627 with a standard error of 0.309 ). In column (2) we repeat the specification constraining the sample to be only foreign multinationals. Although the magnitude of the coefficient on trust is broadly comparable to column (1), the variable is not significant at conventional levels. To examine whether the organizational structure of foreign subsidiaries is influenced by the level of trust prevailing in their country of origin, we add to the baseline specification the average level of trust in the country where the headquarters of the firm owning the plant are located. ${ }^{33}$ Column (3) shows that subsidiaries of firms headquartered in high-trust countries tend to be significantly more decentralized (coefficient 0.767, standard error 0.298). Working with the trust variable measured in the country of origin allows us to include as additional controls a full set of regional dummies. By doing this, we can examine the association between decentralization and trust abstracting for all the time-invariant characteristics of the region of location. In column (4), the inclusion of the regional dummies does

\footnotetext{
${ }^{31}$ See, for example, Helpman, Melitz and Yeaple (2004), Antras, Garicano and Rossi-Hansberg (2008) or Burstein and Monge (2008).

${ }^{32}$ This also includes any potential language or national bias in the interview process, since multinationals are always interviewed in the local language, with the question on the ownership of the firm only asked at the end of the interview.

${ }^{33}$ Note that the clustering is now based on region-country or origin pairings. We did not disaggregate the country of origin variables to the region of origin because the region that a company is headquartered in may be due to purely legal reasons.
} 
not affect the significance and the magnitude of the country of origin trust coefficient, which remains significant at the $5 \%$ level. $^{34}$

A second measure of trust we use is the bilateral trust measure from a series of surveys conducted for the European Commission. These asked around 1,000 individuals in each country the following question "I would like to ask you a question about how much trust you have in people from various countries. For each, please tell me whether you have a lot of trust, some trust, not very much trust, or no trust at all". This question was asked about all other EU countries and a number of non-EU countries like the US, Japan and Canada. In column (5) we restrict the sample to European multinationals for which the have a measure of bilateral trust between their country of origin and their country of location ${ }^{35}$. This measure of bilateral trust is significantly associated with decentralization - subsidiaries of firms in countries the multinational's parent country tends to trust (like French subsidiaries in Belgium) are typically more decentralized than subsidiaries in countries the multinational's parent country does not trust (like French subsidiaries in Britain). In column (6) we include both a full set of country location and origin dummies, so that we are only identifying the trust effect of the pair wise variation in trust. Even in this demanding specification higher bilateral trust is associated with significantly more decentralization.

Finally, in Column (7) we instrument bilateral trust using the approach developed by Guiso et al. (2009). They examine the impact of trust on cross-country trade and investment and find that greater trust appears to encourage both. They develop a set of instruments for trust based on religious and ethnic similarities between pairs of countries ${ }^{36}$. When trust is instrumented with these religious and somatic distance measures our point-estimates for the impact on decentralization remain virtually unchanged, although the larger standard errors mean these are no longer significant at conventional levels. This result is suggestive of a causal effect of trust on decentralization in firms. Interestingly,

\footnotetext{
${ }^{34}$ We experimented by including the Rule of Law index from the multinational's home country, and find that this variable is insignificant (point estimate -0.108 and standard-error 0.092). This suggests that not every factor in the multinational's home country is important for local decentralization, but only those that are likely to be transplanted abroad in the multinational's managerial and organizational structure.

${ }^{35}$ If we re-run the column (4) specification with the column (5) sub-sample the results are very similar, with a pointestimate (standard-error) on the key trust (country of origin) variable of $0.872(0.677)$. This suggests that this sub-sample of European multinationals is representative of the larger sample.

${ }^{36}$ Religious differences are calculated as the product of the fraction of individuals in each country in each religion, and genetic distances as the somatic gap between countries in terms of differences in hair color, facial shape and height (see Appendix for details). The idea is that countries with different religions and different visual appearances are less likely to bilaterally trust each other. Guiso et al. (2009) show these two measures are an important predictor of bilateral trust, and are robust to controls for similarities in law and language, informational overlap and geographic distance.
} 
it also provides one potential mechanism for the Guiso et al. (2009) FDI results. Multinational firms have a greater need to decentralize to foreign subsidiaries due to the local managers' better private information, but will be reluctant to do so when they do not trust the local management. Being able to decentralize will increase the attractiveness of these locations for FDI. This also suggests a crosscountry selection mechanism for industrial location. Industries requiring greater levels of decentralization should operate in higher-trust countries, something we will confirm in sub-section V.C.

\section{V.B Trust and firm size}

In Table 1 we showed that larger firms are more decentralized - in this sub-section we examine whether trust fosters larger average firm size, suggesting an additional route by which social capital fosters decentralization.

To do this we use the population of all public and private firms from our accounting databases detailed in the Data Appendix to measure average firm size in manufacturing (i.e. we do not use the variables in our organizational survey). These databases appear broadly comprehensive for firms with 100 or more employees. ${ }^{37}$ Because of this we use the average size of the population of manufacturing firms with over 100 employees as our main dependent variable. These larger 100+ employee firms are also the group we targeted in our organizational survey. One reason we surveyed this group of 100+ employee firms is because they are likely to require some kind of formal management structure. In smaller firms - say a 10 person factory - the CEO can directly manage all employees, taking all decisions directly.

In column (1) of Table 3 we show that firms in a given region are much larger when trust is higher and Rule of Law is stronger. This is consistent with the earlier cross-country trust results in La Porta et al. (1997) and Kummar, Raghuram and Zingales (2005), and cross-region Rule of Law results in Mexico in Laeven and Woodruff (2007). In column (2) we go beyond the prior literature by including a full set of country dummies and exploiting within country variations in trust which allows us to control other cross country factors that could be generating these results. The coefficient on trust remains positive and significant.

\footnotetext{
37 In some countries like India smaller firms are often unregistered. But for manufacturing firms with over 100 employees this is much less likely, given these firms typically operate with a large production facility which will be hard to keep hidden from the authorities. Given our focus is on the size of firms rather than the size of plants using firm level databases (rather than Census databases on plants) is appropriate.
} 
In columns (3), (4) and (5) we re-estimate our specification from column (2), but for a greater range of the total firm size distribution. The coefficient on trust falls to some extent as we include more of the size distribution which is what we would expect if trust particularly mattered for large firms (from 1.851 for $100+$ employee firms in column (2) to 1.540 for all firms in column (4)). Nevertheless, trust remains significant throughout all columns.

The magnitude of the trust coefficient in column (2) is large - for example moving from the lowest trust region (Assam in India) to the highest trust region (Norrland in Sweden) - would be associated with a 117 log point increase in firm size. Given the importance of large firms for reallocation and aggregate productivity growth, this highlights a potentially important role for social capital and culture in explaining aggregate productivity.

\section{V.C Industry structure and decentralization}

The factors that facilitate greater decentralization within firms should also influence industry composition across regions and countries. If some industries require greater decentralization for efficient production - for example if they are technologically fast moving - then we should see these located in higher trust areas. To investigate this we calculated an "implied industry decentralization”, $I D_{j}$, for each region as follows:

$$
I D_{j}=\sum_{k} E_{j k} \times D_{k}
$$

where $j$ denotes region and $k$ denotes two digit industry, $E_{j k}$ is the share of employment in each two digit industry in each region calculated from the population of all public and private firms in that region (see Appendix), and $D_{k}$ is the average decentralization value for that industry in our sample in the UK. We choose the UK as the base country because (a) it is a relatively high-trust and Rule of Law country where firms are likely to be closer to being optimally decentralized, and (b) we have a large sample of firms in the UK spread across every industry enabling us to generate industry level decentralization measures. ${ }^{38}$ In the regression we then drop the UK, so that our survey data used to generate industry implied decentralization does not overlap with the regions in the regression.

\footnotetext{
${ }^{38}$ We have 570 observations in the UK. The other potential base-country to use is the US with 643 observations. We choose the UK as: (i) it has a more even coverage across industries than the US, which has some industries with small firm numbers; and (ii) it has fewer regions than the US, so since we drop the base country this allows for a larger regression sample. Re-estimating using the US numbers also gives significant trust and rule-of-law results, with for example, the standard errors (point estimates) 0.209 (.037) and 0.059 (0.011) respectively in columns (1) and (2).
} 
In Table 4 we regress $I D_{k}$ the implied industry decentralization measure against trust in the region in column (1) and obtain a significant and positive impact. This implies that high trust regions tend to specialize in industries that are more decentralized. In column (2) we add Rule of Law, which varies only by country, and find a similar result: strong Rule of Law countries have more employment in decentralized industries. In column (3) we include a full set of country controls, and the trust variable, finding similar point estimates but larger standard errors.

In summary, an interpretation of our results is that trust fosters greater decentralization through enabling countries to specialize in industries where decentralization matters more, through fostering FDI and larger firms. Furthermore, even conditional on industry, size and multinational status, high trust regions have more decentralized organizations. Before linking these relations with productivity in the next section, we will examine other determinants of decentralization.

\section{EXTENSIONS: RELIGION AND COMPETITION}

The previous section established the importance of social capital for decentralization. In this section we consider two other key factors that affect decentralization: religion and competition and then consider how well we can account for the cross country variation in firm organization highlighted in Figure 3. We then consider a battery of robustness tests.

\section{VI.A Hierarchical Religions}

As discussed in section II, religion could be linked to the decentralization of firms due to either its indirect impact on trust, or more directly through it links with a managerial "taste" for autonomy. Following La Porta et al (1997), we focus on is the percentage of the population belonging to a “hierarchical religion”, defined as Catholic, Islamic or Eastern Orthodox. The results of the analysis are shown in Table 5. Column (1) starts by regressing the decentralization variable against the religion variable with no extra controls except for GDP per capita and population in the plant's region. Plants located in regions with a high share of hierarchical religions tend to be significantly less decentralized than others. Column (2) shows that the coefficient on hierarchical religion is robust to the inclusion of the Rule of Law index, although since these are negatively correlated, this does substantially reduce the point estimate on hierarchical religions, which falls to -0.268 . Column (3) shows that the hierarchical religion effect is also robust to the inclusion of a full set of country, noise, industry and firm controls. In particular, trust continues to have a significant relationship with 
decentralization, implying that both trust and religion have independent associations with organization. The role of hierarchical religion goes beyond the trust effect highlighted in the prior literature. ${ }^{39}$ The size of this relationship is also large, so for example based on the column (3) specification going from the Swedish to Greek levels of hierarchical religion is associated with a reduction in decentralization of 0.446 , almost half a standard deviation. ${ }^{40}$

In column (4) we instrument religious affiliation using data from five European countries whose acceptance or rejection of the reformation can arguably be claimed to be driven by random events ${ }^{41}$. In each of these five countries we coded each region as unity if they accepted the reformation, and zero otherwise and use this as an instrument. The results show a similarly negative point estimate of -0.764 for the impact of hierarchical religions on decentralization (compared to -0.606 for this sample under OLS). Finally, in Column (5) we use the sub-sample of foreign multinational subsidiaries and find that - similarly to trust - subsidiaries of firms headquartered in countries with a high share of hierarchical religions tend to be significantly less decentralized than others. This suggests the mechanism linking religion with decentralization is transplanted abroad by multinationals.

\section{VI.B Competition}

As discussed in the theory section, many authors have speculated that competition may have stimulated decentralization, perhaps because of the greater time sensitivity of decisions and therefore the greater implied value of the manager's local knowledge. Table 6 examines this for the first time on cross country micro-data with comparable measures of decentralization. We use three broad measures of product market competition following Nickell (1996) and Aghion et al. (2005). The first

\footnotetext{
${ }^{39}$ We ran a series of robustness tests on the column (3) specification. For example dropping the US where religious affiliation is primarily correlated with recent immigration patterns rather than historic variation, and found the point estimate on HIER rises to -0.705 (standard error of 0.235 ). We also regressed decentralization on the shares for individual religious blocks (with atheist as the baseline) and found coefficient (standard errors) of -0.686 (0.224), -1.961 (0.862) and -0.417 (1.021) on the share of Catholics, Orthodox and Muslims in the region respectively.

${ }^{40} 0.446=0.494 *(0.909-0.014)$, where 0.909 and 0.014 are the Greek and Swedish share of hierarchical religions.

${ }^{41}$ Two of these are the Sweden and the UK, whose motivation to undertake the reformation was driven by the need to replenish their King's treasuries following expensive wars with Denmark and France respectively, and in the UK's case also because of the need for Henry VIII to obtain a divorce (Barro and McCleary, 2005). Another two of these countries are France and Poland, whose eventual rejection of the reformation followed a long and unpredictable struggle. In the case of France it became Catholic only after the 36 year Wars of Religion between the protestant Huguenots and the French Catholics. Eventually the Protestant Henry of Navarre was proclaimed King after converting to Catholicism with the famous quote "Paris is worth a mass". In the case of Poland its King Sigmund II, and the majority of the nobility were protestant from the mid 1540s until the 1560s, until the Jesuits launched a successful counter reformation and the country swung back to Catholicism. Finally, Germany itself was sufficiently marginal that the some parts accepted the reformation (the South and West) and other parts did not (the North and East).
} 
measure is the degree of import penetration in the country by two-digit industry measured as the share of total imports over domestic production. This is constructed for the 5-year period 1999-2003 to remove any potential contemporaneous feedback. The second is the country by three digit industry Lerner index of competition, which is (1 - profits/sales), calculated as the average across the entire firm level database (excluding the firms in the survey). Again, this is constructed for the 5year period 2000-2004 to remove any potential contemporaneous feedback. ${ }^{42}$ The third measure of competition is the manager's response to the survey question on the number of competitors a firm faces, valued zero for "no competitors", one for "between one and five competitors", and two for "5 or more competitors”.

In column (1), we see that greater import competition is positively and significantly associated with greater decentralization. In column (2), we re-estimate the same specification but now include a full set of controls including trust, religion, skills, size, multinational status, a full set of country and three-digit industry dummies. Even after conditioning on these additional covariates we find that the more competitive country-industry pairings contain firms that are on average significantly more decentralized. In columns (3) and (4) we run two identical specifications but use the lagged industrylevel (inverse) Lerner index as an alternative measure of competition. We again find a significant and positive association between competition and decentralization. In columns (5) and (6), we run two further similar specifications using the plant manager's own self reported measure of the perceived number of competitors. Again we find a positive and significant association: the more rivals a firm perceives it faces the more decentralized it appears to $\mathrm{be}^{43}$.

\section{VI.C Quantification of cross-country differences in decentralization}

To evaluate the overall explanatory power for decentralization of our four main variables: trust, Rule of Law, religion and competition; we evaluate their $\mathrm{R}^{2}$ in firm, regional and country regressions (with no other explanatory variables). When we do this for the 3,660 firm level observations we find an $\mathrm{R}^{2}$ of $12.8 \%$ (adjusted $\mathrm{R}^{2}$ of $12.6 \%$ ). When we do this at the regional level on the 112 regional observations (taking regional averages of all variables) we find an $\mathrm{R}^{2}$ of $66.3 \%$ (adjusted $\mathrm{R}^{2}$ of

\footnotetext{
42 The 1999 data was not available in the Oriana accounting database for China and Japan, so we used 2000-2004 for all countries.

${ }^{43}$ The magnitude of the competition effect on average decentralisation scores is of economic as well as statistical significance. For example in column (6) increasing the number of competitors from zero to five is associated with an increase in the decentralization index of 0.196, about one fifth of a standard deviation.
} 
65.0\%). And at the country level (taking country averages of all variables) we find an $\mathrm{R}^{2}$ of $83.3 \%$ (adjusted $\mathrm{R}^{2}$ of $73.7 \%$ ).

Hence, at the firm level the predictive power of these variables is limited. In part this reflects the measurement error in our indicator of firm-level decentralization, which our re-rater evaluation in section III.F suggests accounts for about $50 \%$ of the firm-level variation. In addition there are no doubt many other idiosyncratic firm-level factors which influence optimal decentralization.

At the regional level the explanatory power of these variables is substantially larger, presumably because measurement error and firm-level idiosyncratic factors average out. This is visually clear from Figure 7, which plots the actual values for regional decentralization against the predicted values from the regression. Regions like Assam (in India) have a low degree of predicted decentralization because of low trust, weak Rule of Law and low levels of competition. Regions like Upper Norrland (in Sweden) have a high degree of predicted decentralization between of high trust, strong Rule of Law and low levels of hierarchical religion.

At the country level the fit is extremely good with the exception of Japan. This is predicted to have a high level of decentralization because of good trust, strong Rule of Law and low levels of hierarchical religion. But as is shown in Figure 3 Japan displays a centralized organizational structure on average. One puzzling fact is that we find Japanese firms are extremely good at adopting "lean manufacturing" in our survey ${ }^{44}$. Lean manufacturing includes practices such as worker autonomation (limited worker self-management), the involvement of workers in continuous improvement and the ability of workers to stop the production line. What the survey suggests is that plant managers in Japan do not enjoy the same relatively high level of autonomy as their workers do from the plant managers. So decision making rights in Japan appear more concentrated at the top and bottom of the firm, and not in the hands of the plant managers.

\footnotetext{
${ }^{44}$ In the management component of the survey we have two questions on Lean Manufacturing processes, with Japanese firms having the highest average scores for the adoption on Lean Manufacturing by domestic firms, which is unsurprising since Japan is the origin of the "Toyota system".
} 


\section{VI.D Robustness}

To investigate the robustness of the decentralization results, Table 7 reports results where we reestimate our most general specification (column (6) in Table 6) on various sub-samples, with other controls and different measures of decentralization. In general, the results are stable.

The first column of Table 7 simply reproduces the results from column (6) in Table 6 for ease of comparability. The second and third columns re-estimate this on the sub-sample of firms with only one production plant and those with multiple production plants respectively. The trust coefficient has the same sign in both samples, but is larger and more significant in the multi-plant firm sample. This suggests the effect of trust (and competition) is stronger in larger multi-plant firms, consistent with the idea that it is in these more complex organizations where agency issues matter more that these factors are most important.

In columns (4) and (5) we split by whether the CEO is on the production site being interviewed. For the sites where the CEO is not on-site the trust variable has a higher coefficient, consistent with the idea of trust being more important for longer distance relationships. In column (6) we restrict the sample to firms with 250 to 5,000 employees, to restrict to the larger firms in our sample with a slight increase in the key coefficients. In column (7) we restrict the analysis to privately held firms to control for potential sampling bias with publicly listed firms, and again find similar results on the key variables. Column (8) looks at the ten OECD countries, again finding very similar results ${ }^{45}$. Columns (9) and (10) illustrate the results across the domestic and Foreign Multinationals sample showing similar results.

The Bloom and Van Reenen (2007) management practices measure is included in Column (11), which is highly significant suggesting that better runs firms tend to be more decentralized, without changing the trust coefficient. Columns (12) and (13) run robustness tests on the multinationals results. Column (12) displays the results from re-running our baseline specification of column (3) in Table 6, but restricted to the sub-sample of multinational subsidiaries for which we have the global assets, a measure of the multinational group’s overall size. Column (13) includes this global assets measure, which is positive suggesting larger multinationals tend to decentralized more, although not

\footnotetext{
${ }^{45}$ In China and India despite the much smaller sample size (487 firms), the competition and religion variables are still significant (column (9)). In the China and India sample, however, the trust term falls substantially, potentially because of the much more limited variation in this.
} 
significantly after controlling for size of the plant and subsidiary. Column (14) re-runs our baseline specification of column (3) in Table 6, but restricted only to firms who reported having no managers from the multinational's home country. ${ }^{46}$ Trust by country of origin is still statistically significant, suggesting even multinationals who hire domestic employees adopt some organizational practices of their country of origin. Column (15) drops Islam from the definition of a hierarchical religion and finds very similar results, reflecting in part the very low share of Muslims in some of our sample countries. Finally, in column (16) we use our alternative worker autonomy measure, based on questions D6 and D7 in Appendix A, which evaluate the extent to which workers (rather than managers) control the allocation of tasks and the pace of work in the factory. We find the worker autonomy is also significantly increased by higher competition and greater trust.

\section{FIRM-LEVEL PRODUCTIVITY AND DECENTRALIZATION}

A key question in analyzing firm organizational structures is the impact this could have on firm and national productivity. We have suggested that one route through which social capital matters is through allowing more output to be allocated to larger firms. In this section we examine our survey micro data to examine a second route - the within firm association of decentralization with productivity.

Consider the basic firm production function ${ }^{47}$ :

$$
y_{i t}=\alpha_{L} l_{i t}+\alpha_{K} k_{i t}+\alpha_{C} c_{i t}+\alpha_{D} D_{i}+\gamma^{\prime} Z_{i t}+v_{i t}
$$

where $Y=$ deflated sales, $L=$ labor, $K=$ non-IT capital and $C=$ IT capital of firm $i$ at time $t$, and lower case letters denote natural logarithms, e.g. $y=\ln (Y)$. The $Z$ 's are a number of other controls that will affect productivity such as workforce characteristics (the proportion of workers with a degree) and firm characteristics (firm age, whether the firm is listed), a complete set of three digit industry dummies and country dummies. The crucial variable for us this basic specification is the decentralization index, denoted $D$.

\footnotetext{
${ }^{46}$ In our sample we found that multinationals had on average $93.8 \%$ of managers from the location country, $4.1 \%$ from the source country and $2.1 \%$ from all other countries. Hence, medium sized manufacturing firms appear to typically employ domestic managers in their overseas subsidiaries.

${ }^{47}$ There is an extensive literature on the interpretation of the coefficients in these equations. In particular, in the absence of firm-specific prices the coefficients on the factor inputs should be interpreted as a mix of "true" productivity parameters and a mark-up term (e.g. Foster, Haltiwanger and Syverson, 2008).
} 
In column (1) of Table 8 we run a basic specification with only capital, labor and decentralization, and find a large significant coefficient on decentralization. The coefficient suggests a one standard deviation increase in decentralization is associated with a $10 \%$ increase in productivity. In column (2) we include the full set of control variables, including the education of the workforce, country and industry controls. In this case the coefficient on decentralization falls substantially to 0.023 and is now significant at the $10 \%$. This suggests that there is weak direct association of decentralization with higher productivity.

But while decentralization may only have a small direct association with productivity, it interacts with individual factors of production. To investigate this we need to augment our estimating equation to include interactions with all factor inputs:

$$
y_{i t}=\alpha_{L} l_{i t}+\alpha_{K} k_{i t}+\alpha_{C} c_{i t}+\alpha_{D} D_{i}+\alpha_{L D}\left(l_{i t} * D_{i}\right)+\alpha_{K D}\left(k_{i t} * D_{i}\right)+\alpha_{C D}\left(c_{i t} * D_{i}\right)+\gamma^{\prime} Z_{i t}+v_{i t}
$$

We do this because of a growing prior literature suggesting that decentralized firms may use Information Technologies (IT) more effectively. ${ }^{48}$ One rationalization is that to effectively use new technologies they need local flexibility to experiment. In a decentralized organization that can be achieved locally, while in a centralized organization this will have to be enforced from the centre which may be much harder to do. We also include interactions with employment and non-IT capital because the organization of the firm may also influence the productivity of these factors.

In column (3) we see the IT *decentralization interaction is positive and significant, consistent with this prior literature that IT is more effectively used in decentralized firms. In column (4) we re-run this estimation including a full set of firm-level fixed effects to control for any other unobserved cross-sectional factors, and again find a positive and significant coefficient (note that the linear time invariant variables are not separately identified from the firm specific effects). In column (5) we add an interaction between decentralization and non-IT capital and find a significant negative coefficient, suggesting more traditional non-IT capital may actually be better utilized in a more centralized firm. Similar experiments with employment and skills interactions with decentralization were not significant. $^{49}$

\footnotetext{
${ }^{48}$ See, for example, Bresnahan et al (2002) and Bartel, Ichinowski and Shaw (2007).

${ }^{49}$ For example, the point estimate (standard-error) on running a similar regression for employment interacted with decentralization was 0.0188 (0.0389), and for skills interaction with decentralization was -0.153 (0.105).
} 
The magnitude of the coefficient on the IT and decentralization interaction at 0.032 is quantitatively important. The reason is the real IT capital stock has been growing by about $8 \%$ a year faster than non-IT capital inputs in Europe and the $\mathrm{US}^{50}$, so that a firm (or country) with one standard-deviation higher decentralization would have about 0.26 percentage points faster annual productivity growth.

\section{CONCLUSIONS}

The focus of our paper is analyzing the argument that social capital enhances macro-economic performance through affecting the internal organization of firms. High trust and strong rule of law regions are able to sustain larger firms and industrial sectors that require decentralization; further companies in these regions also have a higher degree of delegation given their size and industry. Trust is even important when we look at subsidiaries of multinational firms - delegation is much more likely for pairs of countries with high bilateral trust. Trust and rule of law enhance national productivity because efficient firms need to decentralize when they grow, and recent work has demonstrated that such reallocation is a key factor in aggregate productivity both for developed and developing countries.

A second contribution of our paper is to provide some data infrastructure for the analysis of firm organization. Despite many theoretical advances, the empirical literature on organizational economics lacks comparable measures of firms' internal organization across countries. By collecting original data on decentralization across many thousands of firms in twelve countries we start to address this lacuna. We find that American and Northern European firms are much more decentralized than those from Southern Europe and Asia. These cross country differences can be largely accounted for by four key factors: trust, the Rule of Law, hierarchical religion and competition.

Since the importance of decentralization appears to be growing, countries with a comparative advantage in decentralization (whether through high trust, stronger Rule of Law and less hierarchical religion) such as the US and Northern Europe are likely to have benefit disproportionately. If the trend towards rapid technical change and greater competition in markets continues this is likely to give productivity advantages to such countries.

\footnotetext{
${ }^{50}$ Calculated from 1994 to 2004 using the Groningen Growth and Development Centre dataset for Europe and the US.
} 
There are many future directions for this work. First, some of the findings need to be matched up with new developments in theory (e.g. Alonso, Dessein and Matouschek, 2008, have examined coordination models that could rationalize the competition results). Second, the role of changes in ICT needs to be unpacked. We have simply used a composite hardware measure as is standard in the literature but Garicano (2000) and Garicano and Rossi-Hansberg (2008) have correctly stressed that the impact of falls in information costs on delegation are often the opposite of falls in communication costs in "cognitive” models of the firm. This model can potentially be empirically tested using the kind of data developed here. 


\section{BIBLIOGRAPHY}

Acemoglu Daron, Philippe Aghion, Claire Lelarge, John Van Reenen, and Fabrizio Zilibotti (2007) "Technology, Information and the Decentralization of the Firm”, Quarterly Journal of Economics, 122(4), 1759-1799.

Aghion, Philippe, Yann Algan, Pierre Cahuc, and Andrei Shleifer (2008) "Regulation and Distrust”, Harvard mimeo.

Aghion, Philippe, Nick Bloom, Richard Blundell, Rachel Griffith and Peter Howitt (2005) "Competition and Innovation: An Inverted U Relationship", Quarterly Journal of Economics, 120(2), 701-728.

Aghion, Philippe, and Jean Tirole (1997) “Formal and Real Authority in Organizations”, Journal of Political Economy, 105(1), 1-29.

Allen, Douglas (1995) “Order in the Church: A Property Rights Approach”, Journal of Economic Behavior and Organization, 27(1), 97-117.

Alonso, Ricardo, Wouter Dessein and Niko Matouschek (2008) "When Does Coordination Require Centralization”, American Economic Review, 98(1), 145-179.

Antras, Pol, Luis Garicano and Esteban Rossi-Hansberg (2008) “Organizing Offshoring: Middle Managers and Communication Costs”, in Elhanan Helpman, Dalia Marin, and Thierry Verdier (eds), The Organization of Firms in a Global Economy, Harvard University Press.

Arzaghi, Mohammad and Vernon Henderson (2005) "Why Countries Are Fiscally Decentralizing”, Journal of Public Economics, 89(7), 1157-1199.

Baker, George, Robert Gibbons, and Kevin Murphy (1999) "Informal Authority in Organizations”, Journal of Law, Economics, and Organization, 15(1), 56-73.

Baker, George, and Thomas Hubbard (2003) "Make Versus Buy in Trucking: Asset Ownership, Job Design and Information”, American Economic Review, 93(3), 551-572.

Baker, George, and Thomas Hubbard (2004) "Contractibility and Asset Ownership: On Board Computers and Governance in US Trucking”, Quarterly Journal of Economics, 119(4), 1443-1479.

Banerjee, Abhijit and Ester Duflo (2005) “Growth Through the Lens of Development Economics”, in Philippe Aghion and Stephen Durlauf (eds), Handbook of Economic Growth, Volume 1 of Handbook of Economic Growth, Chapter 7, pp. 473-552. Amsterdam: Elsevier.

Baron, David, and David Besanko (1992) “Information, Control, and Organizational Structure”, Journal of Economics and Management Strategy, 1(2), 237-275.

Barro, Robert and Rachel McCleary (2005) "Which Countries Have State Religions”, Quarterly Journal of Economics, 120(4), 1331-1370. 
Barro, Robert and Rachel McCleary (2006), "Religion and Economy”, Journal of Economic Perspectives, 20(2), 49-72.

Biasutti, Renato, (1959), “Le Razze e i popoli della terra”, Volumes 1 and 2, Turin: UTET.

Bloom, Nicholas, and John Van Reenen (2007) "Measuring and Explaining Management Practices across Firms and Countries”, Quarterly Journal of Economics, 122(4), 1341-1408.

Bloom, Nicholas, Raffaella Sadun, and John Van Reenen (2007) “Americans do IT Better: American Multinationals and the Productivity Miracle”, NBER Working Paper No. 13085.

Bloom, Nicholas, Luis Garicano, Raffaella Sadun and John Van Reenen (2009) "The Distinct Effects of Communication and Information Technologies”, LSE/Stanford mimeo.

Bollard, Albert (2009) “Size Distribution in India Manufacturing”, Stanford mimeo.

Bolton, Patrick, and Mathias Dewatripont (1994) “The Firm as a Communication Network", Quarterly Journal of Economics, 109(4), 809-839.

Bolton, Patrick, and Mathias Dewatripont (2005) Contract Theory, Cambridge: MIT Press.

Bresnahan, Timothy, Erik Brynjolfsson, and Lorin Hitt (2002) "Information Technology, Workplace Organization and the Demand for Skilled Labor: Firm-level Evidence”, Quarterly Journal of Economics, 117(1), 339-376.

Burstein, Ariel and Alexander Monge-Naranjo (2008), "Foreign Know-How, Firm Control, and the Income of Developing Countries”, Quarterly Journal of Economics, 124(1), 149-195.

Caroli, Eve, and John Van Reenen (2001) "Skill Biased Organizational Change”, Quarterly Journal of Economics, 116(4), 1449-1492.

Chandler, Alfred (1962) Strategy and Structure: Chapters in the History of the Industrial Enterprise, MIT Press.

Colombo, Massimo, and Marco Delmastro (2004) "Delegation of Authority in Business Organizations: An Empirical Test”, Journal of Industrial Economics, 52(1), 53-80.

Dessein, Wouter (2002) “Authority and Communication in Organizations”, Review of Economic Studies, 69(4), 811-838.

Fernandez, Raquel and Alessandra Fogli (2007) "Culture: An Empirical Investigation of Beliefs, Work, and Fertility”, NYU mimeo.

Fisman, Ray and Edward Miguel (2007) “Corruption, Norms and Legal Enforcement: Evidence from Diplomatic Parking Tickets”, Journal of Political Economy, 115(6), 1020-1048.

Foster, Lucia, John Haltiwanger and C. Krizon, (2000), “Aggregate Productivity Growth: Lessons from Microeconomic Evidence” in Charles Hulten, Edwin Dean and Michael Harper (eds) New Developments in Productivity Analysis, Chicago, IL: University of Chicago Press. 
Foster, Lucia, John Haltiwanger and C. Krizon (2006), "Market Selection, Reallocation and Restructuring in the U.S. Retail Trade Sector in the 1990s", Review of Economics and Statistics, 88(4), 748-758.

Foster, Lucia, John Haltiwanger and Chad Syverson (2008) "Reallocation, Firm Turnover, and Efficiency: Selection on Productivity or Profitability?” American Economic Review, 98(1), 394-425

Fukuyama, Francis (1995) Trust: The Social Virtues and the Creation of Prosperity, New York: Free Press.

Garicano, Luis and Rossi-Hansberg, Estaban (2008) “Organizing Growth” NBER Working Paper No. 13705

Garicano, Luis (2000) "Hierarchies and the Organization of Knowledge in Production", Journal of Political Economy, 108(5), 874-904.

Garicano, Luis, and Thomas Hubbard (2007) "Managerial Leverage is Limited by the Extent of the Market: Hierarchies, Specialization, and the Utilization of Lawyers' Human Capital.”, Journal of Law and Economics, 50(1), 1-43.

Geanakoplos, John, and Paul Milgrom (1991) “A Theory of Hierarchies Based on Limited Managerial Attention”, Journal of the Japanese and International Economies, 5(3), 205-225.

Greif, Avner (1993) "Contact Enforceability and Economic Institutions in Early Trade: The Maghribi Traders Coalition”, American Economic Review, 83(3), 525-548.

Gibbons, Robert and John Roberts (2008) The Handbook of the Organizational Economics, Princeton: Princeton University Press.

Giuliano, Palo (2007) “Living Arrangements in Western Europe: Does Cultural Origin Matter?”, Journal of the European Economic Association, 5(5), 927-952.

Glaeser, Edward, David Laibson, Jose Scheinkman, and Christine Soutter (2000) “Measuring Trust”, Quarterly Journal of Economics, 115(3), 811-846.

Guadalupe, Maria and Julie Wulf (2007) “The Flattening Firms and Product Market Competition: The Effects of Trade Costs and Liberalization”, Columbia University mimeo.

Guiso, Luigi, Paola Sapienza and Luigi Zingales (2003) "People’s Opium? Religion and Economic Attitudes”, Journal of Monetary Economics, 50(1), 225-282.

Guiso, Luigi, Paola Sapienza and Luigi Zingales (2004) "The Role of Social Capital in Financial Development”, American Economic Review, 94(3), 526-554.

Guiso, Luigi, Paola Sapienza and Luigi Zingales (2006) "Does Culture Affect Economic Outcomes?”, The Journal of Economic Perspectives, 20(2), 23-48. 
Guiso, Luigi, Paola Sapienza and Luigi Zingales (2009) “Cultural Biases in Economic Exchange”, forthcoming Quarterly Journal of Economics.

Hart, Oliver, and John Moore (2005) "On the Design of Hierarchies: Coordination versus Specialization”, Journal of Political Economy, 113(4), 675-702.

Helpman, Elhanan, Marc Melitz, and Stephen Yeaple (2004) "Export Versus FDI with Heterogeneous Firms”, American Economic Review, 94(1), 300-316.

Hsieh, Chiang-Tai and Pete Klenow (2007), "Misallocation and Manufacturing TFP in China and India”, NBER working paper 13290.

Hofstede, Geert (2001) Culture’s Consequences, Sage Publications.

Ichino, Andrea and Giovanni Maggi (2000) "Work Environment and Individual Background: Explaining Regional Shirking Differentials in a Large Italian Firm”, Quarterly Journal of Economics, 115(3), 1057-1090.

Jorgenson, Dale, Mun Ho, and Kevin Stiroh (2008) "A Retrospective Look at the US Productivity Growth Resurgence”, Journal of Economic Perspectives, 22(1), 3-24.

Kastl, Jakub, David Martimort, and Salvatore Piccolo (2008) "Delegation and R\&D Incentives: Theory and Evidence from Italy”, Stanford mimeo.

Kaufmann, Danny, Aart Kraay, and Massimo Mastruzzi (2006) "Governance Matters V: Governance Indicators for 1996-2005”, World Bank.

Knack, Stephen and Philip Keefer (1997) "Does Social Capital have an Economy Payoff? A Crosscountry Investigation”, Quarterly Journal of Economics 12(4), 1251-1288.

Kummar, Krishna; Rajan Raghuram and Luigi Zingales, (2005), “What Determines Firms Size?” Chicago GSB mimeo.

La Porta, Rafael, Florencio Lopez-de-Silanes, Andrei Shleifer and Robert Vishny (1997) “Trust in Large Organizations”, American Economic Review, 87(2), 333-338.

Laeven, Luc and Christopher Woodruff (2007) “The Quality of the Legal System, Firm Ownership, and Firm Size”, Review of Economics and Statistics, 89(4), 601-614.

Lucas, Robert E. Jr. (1978) “On the Size Distribution of Business Firms", Bell Journal of Economics, 9: 508-523.

Marin, Dalia and Thierry Verdier (2006) "Corporate Hierarchies and the Size of Nations: Theory and Evidence”, Paris School of Economics mimeo.

Melumad, Nahum, Dilip Mookherjee, and Stefan Reichelstein (1995) “Hierarchical Decentralization of Incentive Contracts”, Rand Journal of Economics, 26(4), 654-672. 
Mookherjee, Dilip (2006), "Decentralization, Hierarchies and Incentives: A Mechanism Design Approach”, Journal of Economic Literature, 44(2), 367-390.

Nickell, Steve (1996), “Competition and Corporate Performance”, Journal of Political Economy, 104(4), 724-746.

Pawasutipaisit, Anan and Robert Townsend (2009), “Wealth Accumulation and Factors Accounting for Success”, MIT mimeo.

Penrose, Edith Tilton (1959) Theory of the Growth of the Firm, New York: J. Wiley \& Sons.

Prendergast, Canice (2002) “The Tenuous Trade-Off between Risk and Incentives”, Journal of Political Economy, 110(5), 1071-102.

Putnam, Robert (1993), Making Democracy Work: Civic Traditions in Modern Italy, Princeton NJ: Princeton University Press.

Radner, Roy (1993) “The Organization of Decentralized Information Processing”, Econometrica, 61: 1109-1146.

Radner, Roy, and Timothy Van Zandt (1992) "Information Processing in Firms and Returns to Scale”, Annales d'Economie et de Statistique, 25/26: 265-298.

Rajan, Raghuram, and Luigi Zingales (2001) "The Firm as a Dedicated Hierarchy: A Theory of the Origin and Growth of Firms”, Quarterly Journal of Economics, 116(3), 805-851.

Rajan, Raghuram, and Julie Wulf (2006) "The Flattening Firm: Evidence from Panel Data on the Changing Nature of Corporate Hierarchies”, Review of Economics and Statistics, 88(4), 759-773.

Sah, Raaj, and Joseph Stiglitz (1986) “The Architecture of Economic Systems: Hierarchies and Polyarchies”, American Economic Review, 76(4), 716-727.

Sapienza, Paola, Anna Toldra, and Luigi Zingales (2007) “Understanding Trust”, NBER Working Paper 13387.

Timmer, Marcel, Gerard Ypma and Bart van Ark (2003) "IT in the European Union: Driving Productivity Divergence?”, Gronnigen Research Memorandum No. 67.

Weber, Max (1930) The Protestant Ethic and the Spirit of Capitalism, London: Allen \& Unwin. 
FIGURE 1 - EXAMPLES OF FIRM ORGANIZATIONAL STRUCTURES
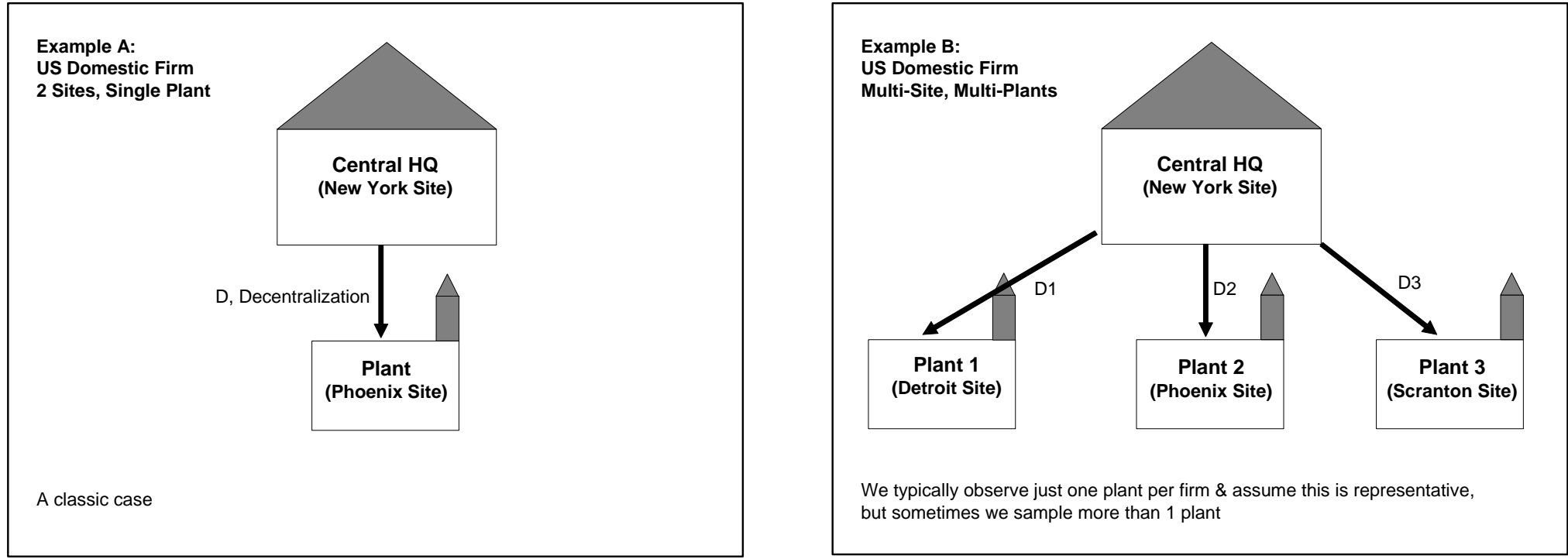

\section{Example C:}

US Domestic Firm

Single site, Single plant

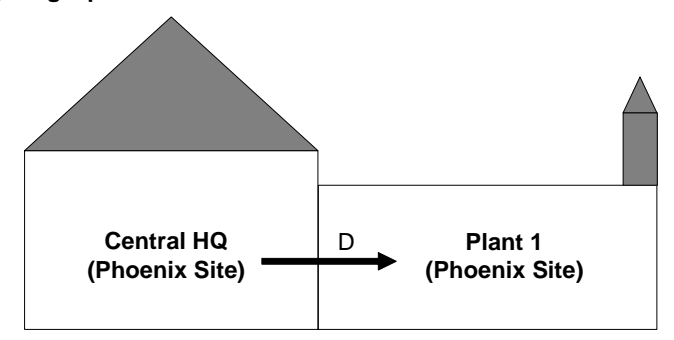

Some firms have a site with multiple "buildings", such as a $\mathrm{CHQ}$ and production

plants. We only keep these if the plant manager is not the CEO, as decentralization is still possible even if the CEO is on-site (think of Universities, which typically have one-site but Departmental Heads have some autonomy from the Dean). We also test robustness to this assumption in Appendix A.

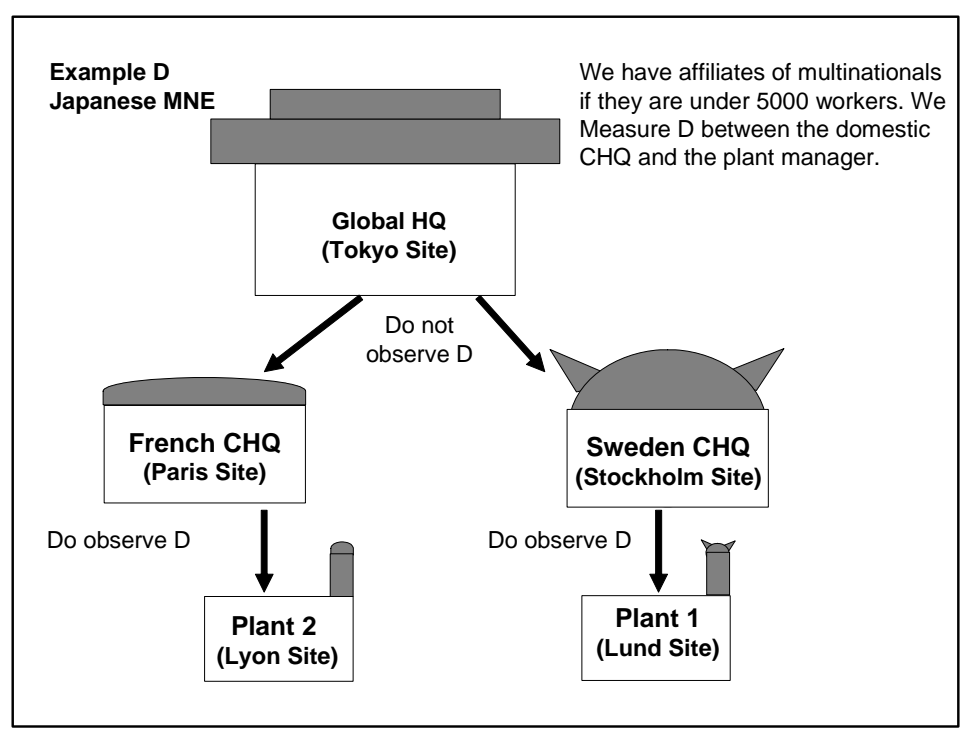


FIGURE 2A - TRUST BY COUNTRY AND REGIONAL DISPERSION

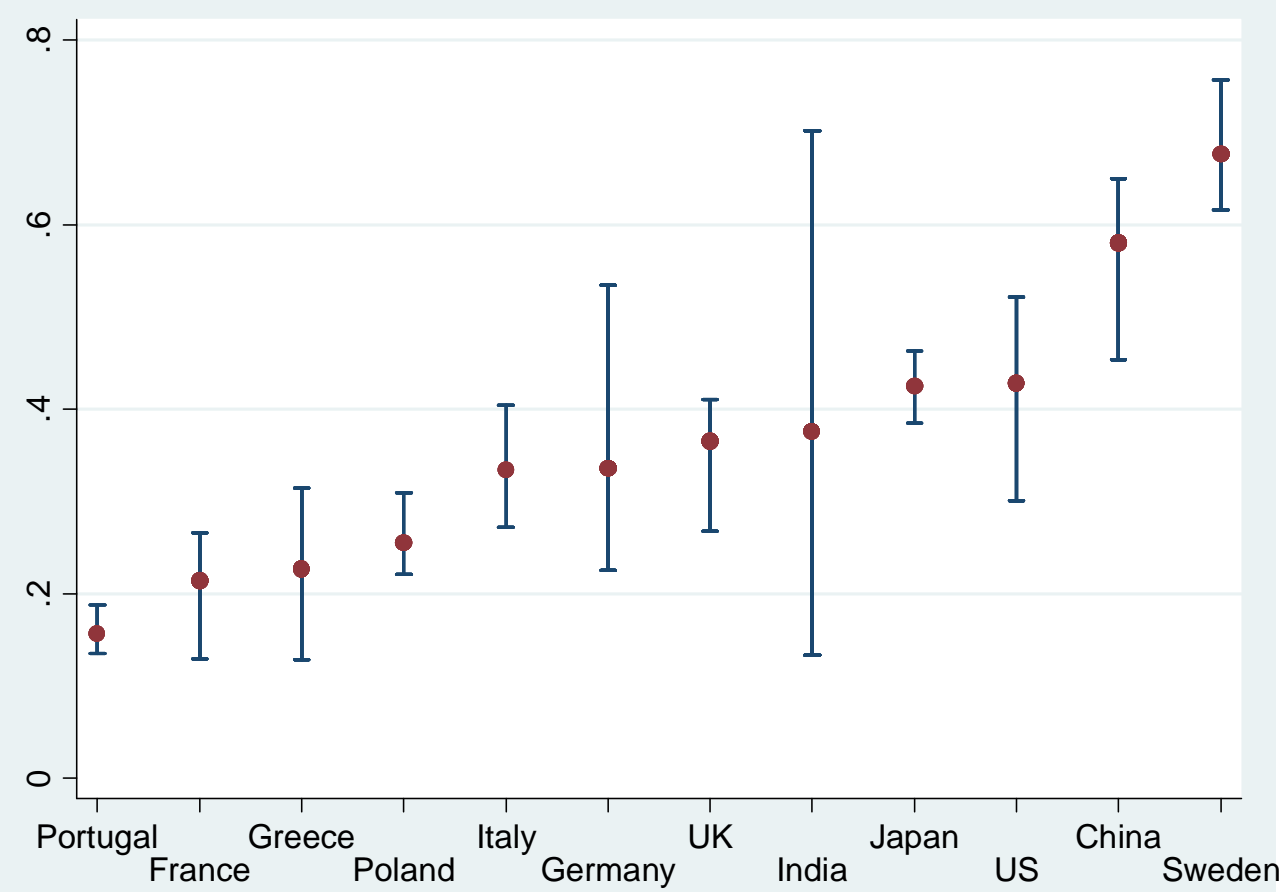

Notes: The graph shows median level of trust. The vertical bars denote minimum and maximum levels.

FIGURE 2B - HIERARCHICAL RELIGION COUNTRY AND REGIONAL DISPERSION

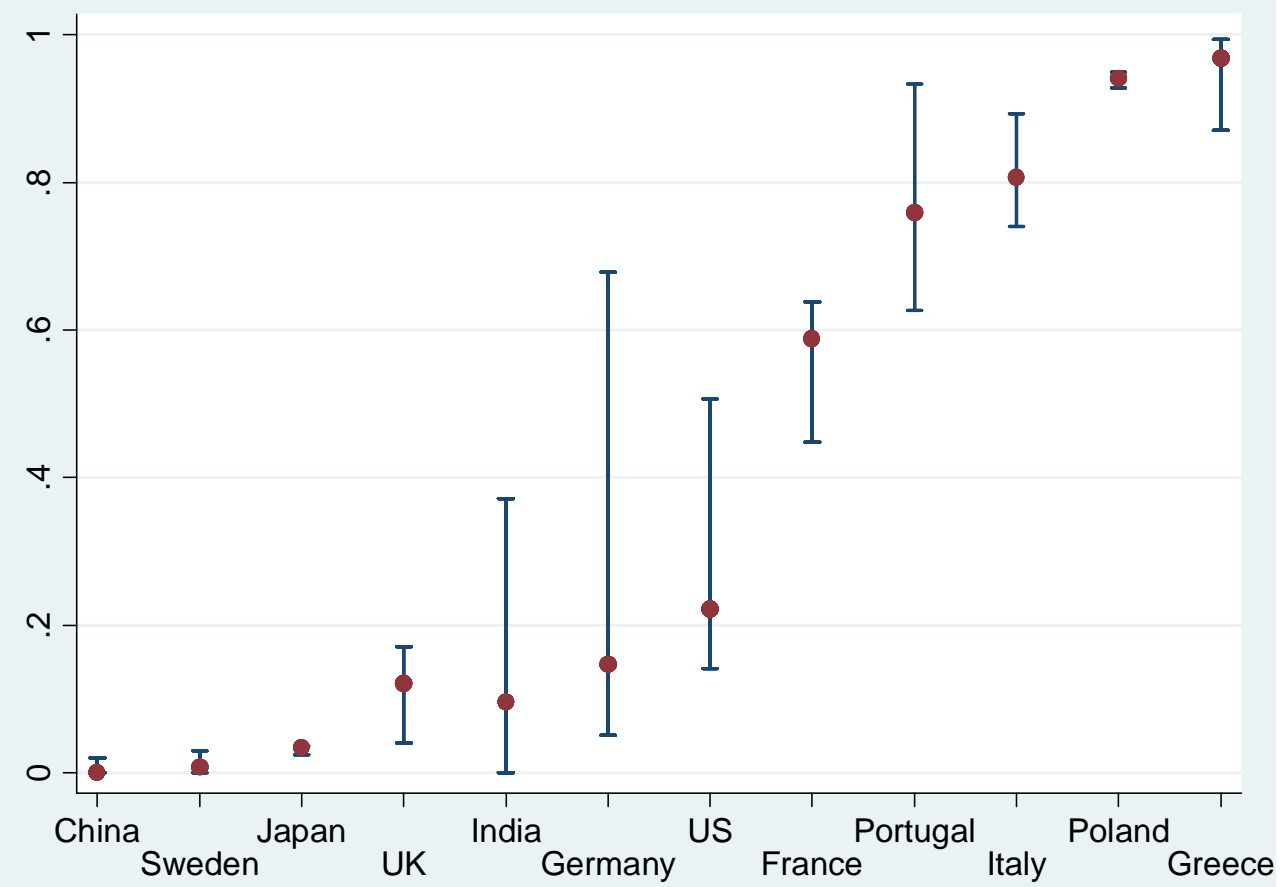

Notes: The graph shows median level of hierarchical religion. The vertical bars denote minimum and maximum levels. 
FIGURE 3 - AVERAGE DECENTRALIZATION BY COUNTRY

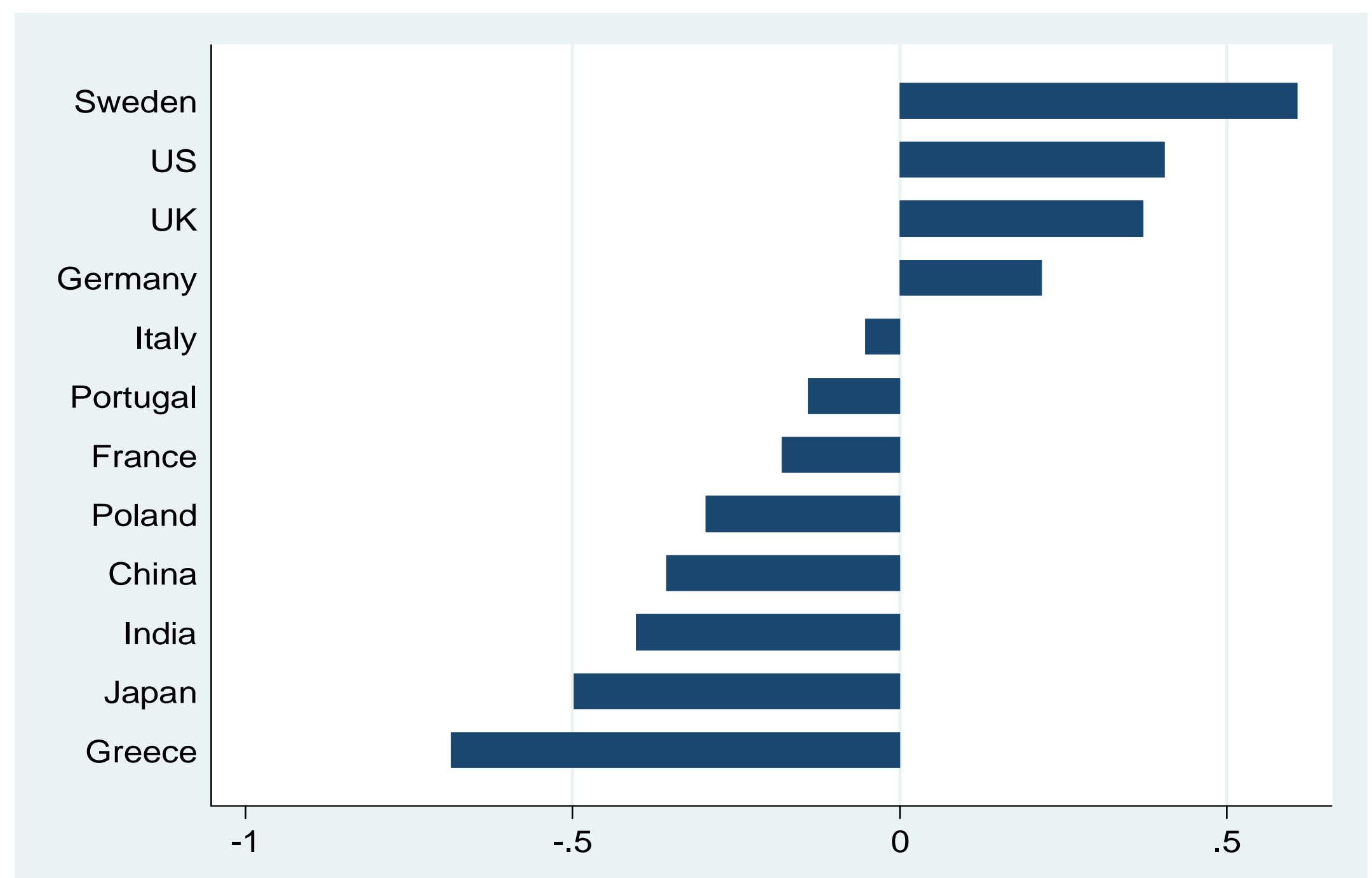

Notes: The graph plots average the z-scored decentralization index by country, measured as the plant manager's degree of autonomy over hiring, investment, products and prices. $\mathrm{N}=3549$. Higher scores indicate more decentralization. 
FIGURE 4 - DISTRIBUTION OF THE DECENTRALIZATION VARIABLE BY COUNTRY

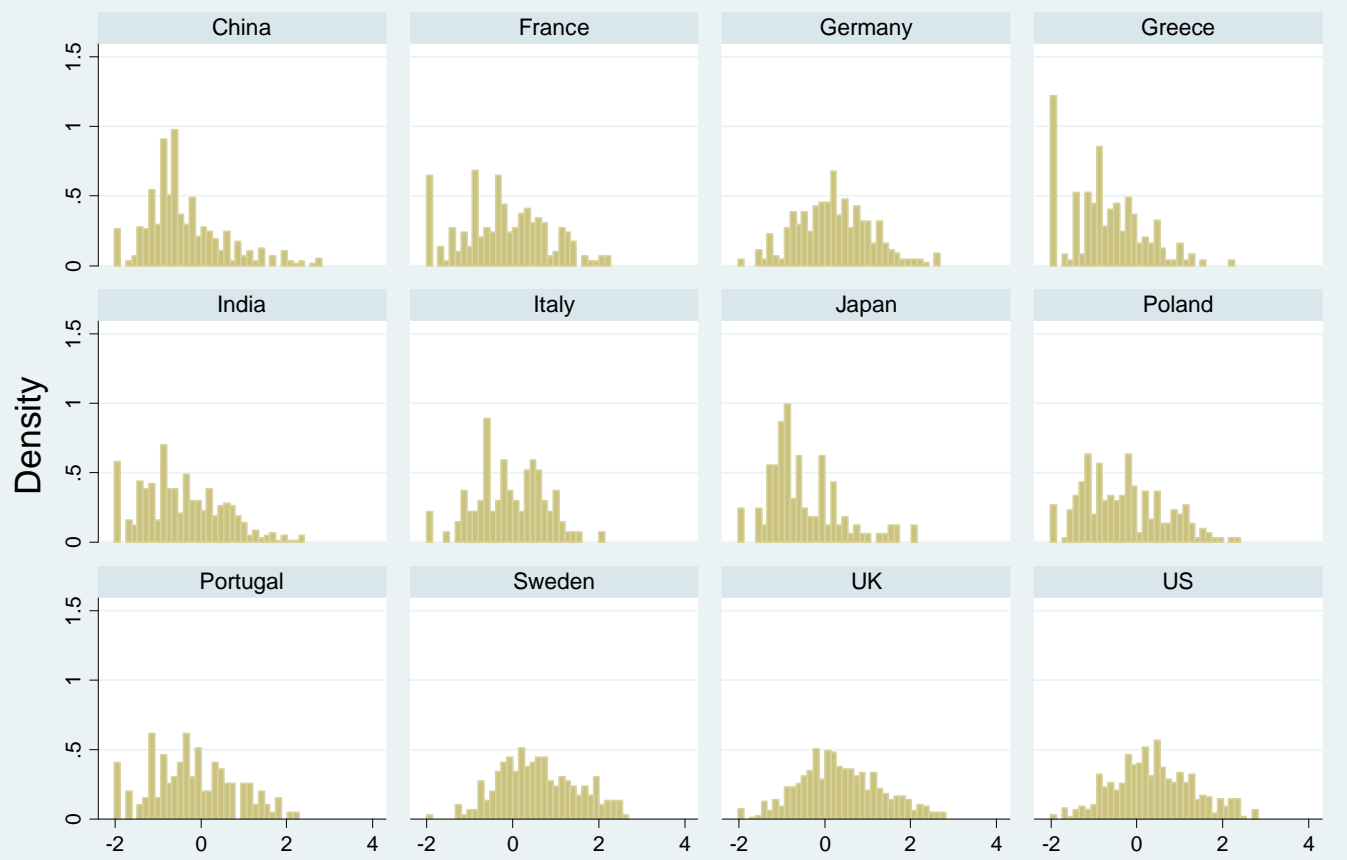

NOTES: These are the distributions of the decentralization index, which measures the degree of autonomy of plant managers over hiring, investment, products and prices. $\mathrm{N}=3549$. Higher scores indicate more decentralization.

\section{FIGURE 5 - DECENTRALIZATION AND POWER DISTANCE INDEX BY COUNTRY}

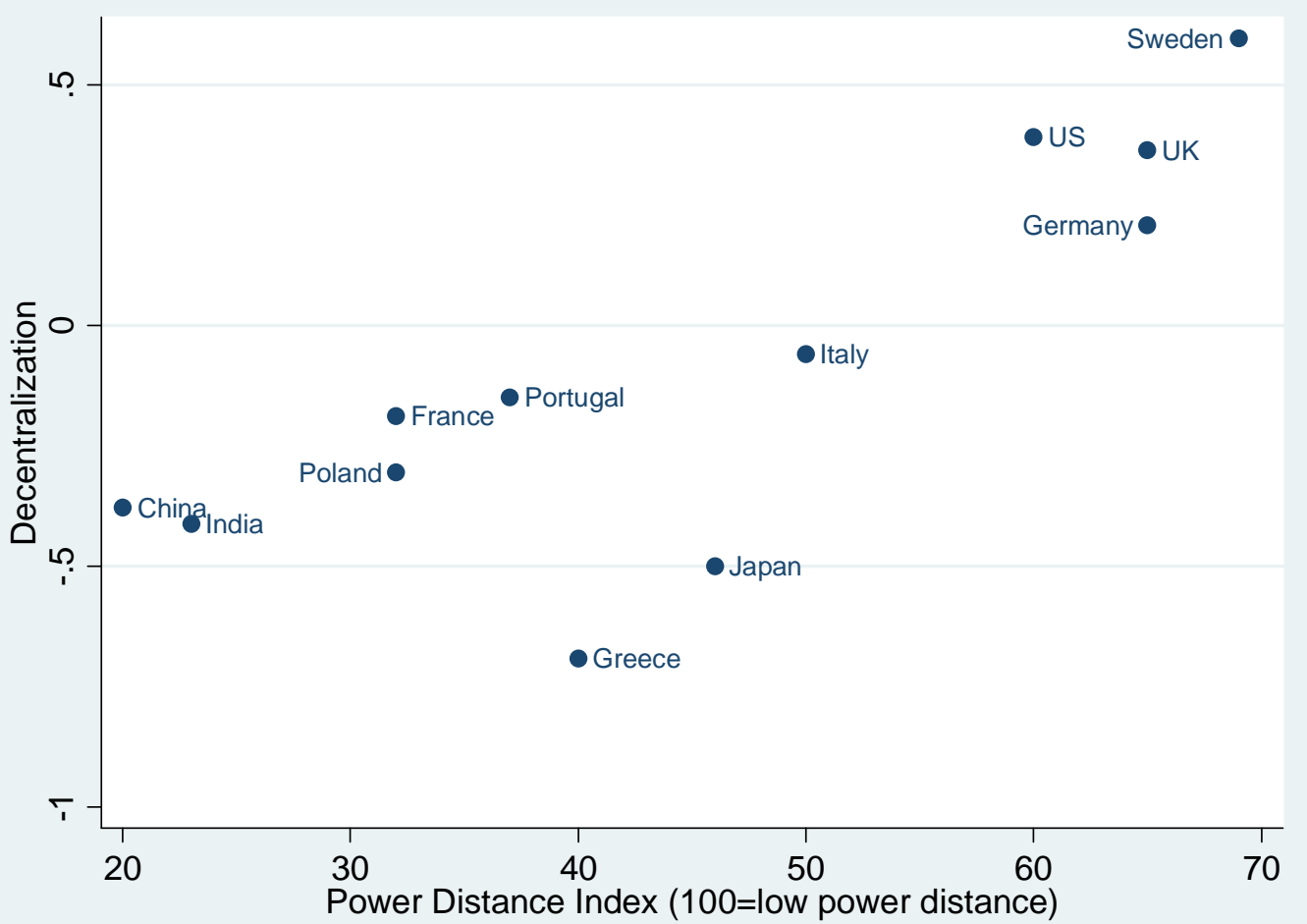

Notes: The y-axis is the average level of autonomy of plant managers over hiring, investment, products and pricing by country. The x-axis is Hofstede's (1980) Power Distance Index. 


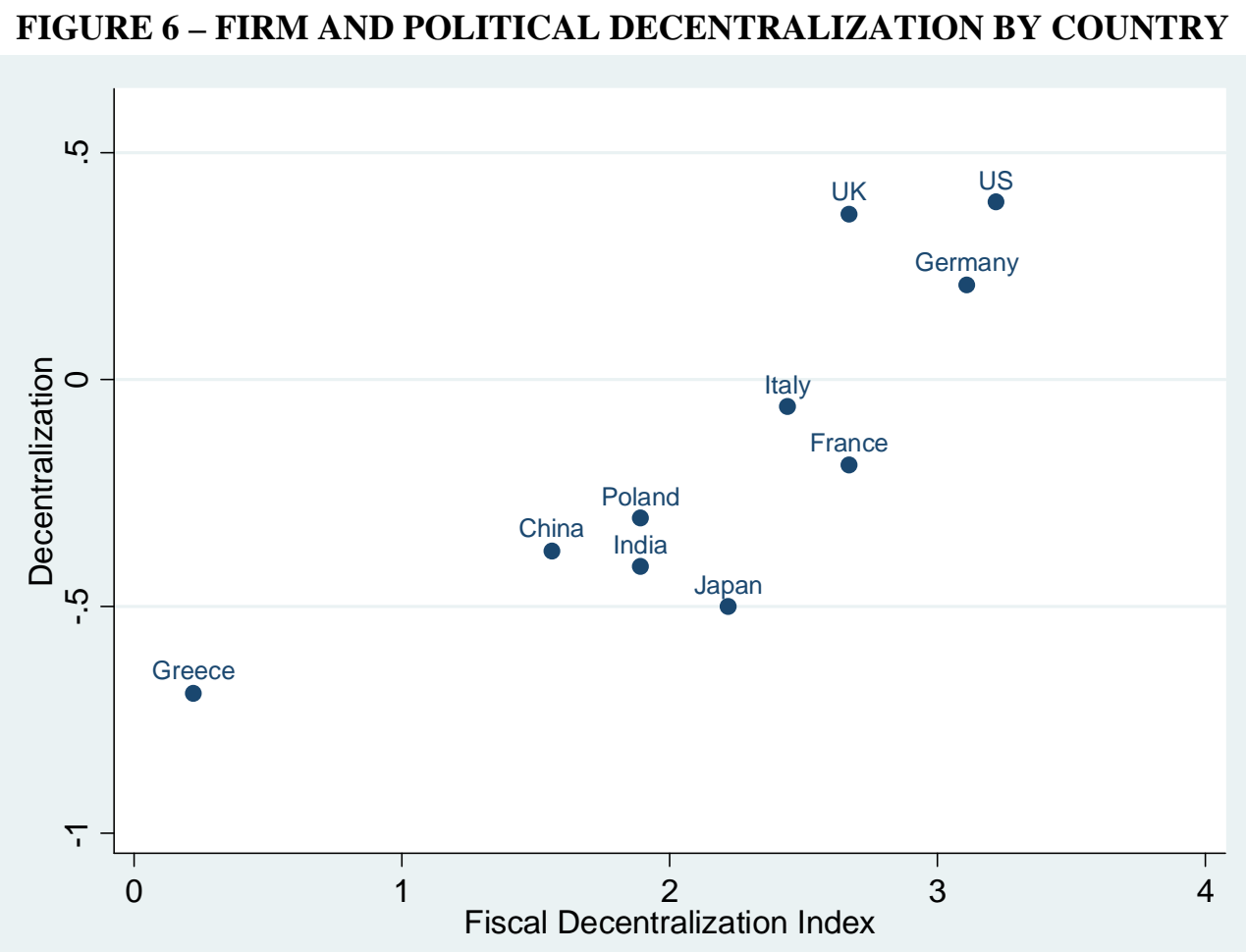

Notes: The y-axis is the average level of autonomy of plant managers over hiring, investment, products and pricing by country. The x-axis is Arzaghi and Henderson’s (2003) Fiscal Decentralization Index.

FIGURE 7 - QUANTIFICATION, BY REGION

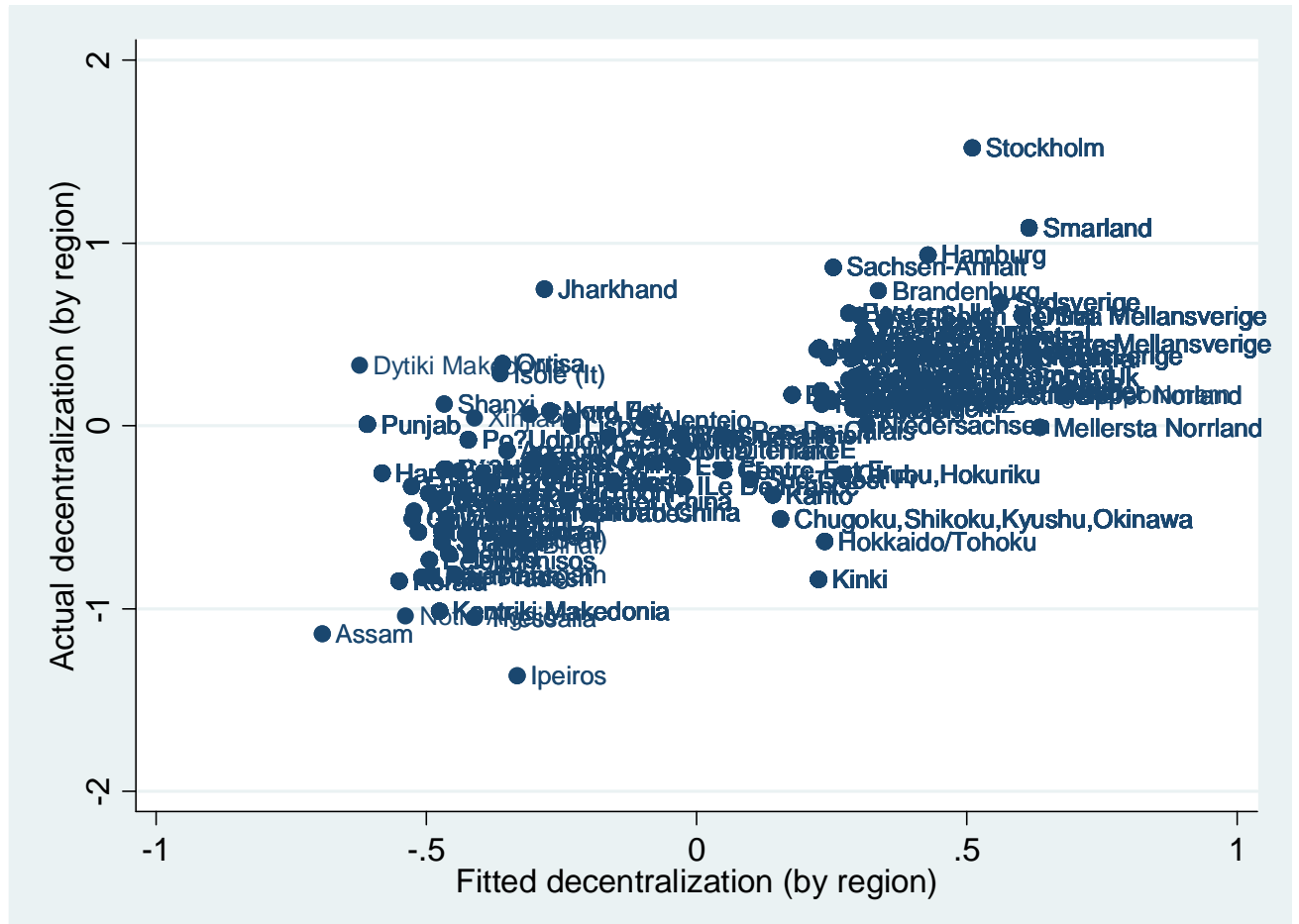

Notes: The y-axis is average regional decentralization z-score, measured as the average scores for firms within the region on their plant manager's degree of autonomy over hiring, investment, products and pricing. The $\mathrm{x}$-axis is regional decentralization z-score predicted from our measures of regional trust, regional share of hierarchical religion and country Rule of Law. 
TABLE 1

DECENTRALIZATION AND TRUST

\begin{tabular}{|c|c|c|c|c|}
\hline "Dependent variable: Decentralization & 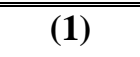 & 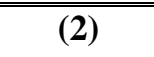 & 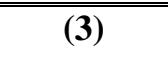 & (4) \\
\hline Trust (region) & $1.115^{* *}$ & $0.857 * * *$ & $0.795^{* * *}$ & $0.699 * *$ \\
\hline Trust measured in plant's region of location & $(0.437)$ & $(0.303)$ & $(0.303)$ & $(0.317)$ \\
\hline $\begin{array}{l}\text { Rule of Law (country) } \\
(-2.5=\text { low, } 2.5=\text { high })\end{array}$ & & $\begin{array}{c}0.515^{* * *} \\
(0.125)\end{array}$ & $\begin{array}{c}0.531 * * * \\
(0.121)\end{array}$ & \\
\hline $\begin{array}{l}\text { Plant Skills } \\
\text { \% Plant employees with a College degree }\end{array}$ & & & & $\begin{array}{c}0.085^{* * *} \\
(0.015)\end{array}$ \\
\hline $\begin{array}{l}\text { Firm Size } \\
\text { In(Firm employment) }\end{array}$ & & & $\begin{array}{c}0.106^{* * *} \\
(0.021)\end{array}$ & $\begin{array}{c}0.052 * * \\
(0.022)\end{array}$ \\
\hline Plant employment & & & $0.119 * * *$ & $0.089 * * *$ \\
\hline Plant employees as a \% of firm & & & $(0.025)$ & $(0.030)$ \\
\hline Foreign Multinational & & & & $0.157 * * *$ \\
\hline Dummy=1 if firm belongs to a foreign multinational & & & & $(0.058)$ \\
\hline Domestic Multinational & & & & 0.018 \\
\hline Dummy $=1$ if firm belongs to a domestic multinational & & & & $(0.040)$ \\
\hline Observations & 3,660 & 3,660 & 3,660 & 3,660 \\
\hline Country controls (2) & no & yes & yes & - \\
\hline Regional controls (2) & no & no & no & yes \\
\hline Industry dummies (112) & no & no & no & yes \\
\hline Country dummies (12) & no & no & no & yes \\
\hline Other controls (60) & no & no & no & yes \\
\hline
\end{tabular}

Notes: * significant at $10 \%$; ** significant at 5\%; *** significant at $1 \%$. The dependent variable is the decentralization $\mathrm{z}-$ score index, measured by plant manager's autonomy over hiring, investment, products and pricing. Estimation by OLS with robust standard errors in parentheses. Standard errors clustered by the firm's region of location. TRUST measures the percentage of individuals who agreed with the statement "most people can be trusted" in the firm's region of location. RULE OF LAW measures the extent to which agents have confidence in and abide by the rules of society, and in particular the quality of contract enforcement, the police, and the courts, as well as the likelihood of crime and violence. The index is compiled by the World Bank (Kauffman et al, 2007), and ranges between -2.5 and 2.5. "Other controls" include a dummy for whether the firm is publicly listed, a dummy for whether the CEO is on the same site as the plant ("CEO onsite") and "Noise controls" (these include 44 interviewer dummies, 6 dummies to control for the day of the week the interview took place, an interview reliability score, the manager's seniority and tenure, the duration of the interview, and 4 dummies for missing values in seniority, tenure, duration and reliability). Country controls are GDP per capita and population. Regional controls are GDP per capita and population in the region. Regressions weighted by the share of World Values Survey respondents in the region in the country. 
TABLE 2

DECENTRALIZATION AND TRUST IN THE COUNTRY OF ORIGIN

\begin{tabular}{|c|c|c|c|c|c|c|c|}
\hline Dependent variable: & (1) & (2) & (3) & (4) & (5) & (6) & (7) \\
\hline Decentralization & OLS & OLS & OLS & OLS & OLS & OLS & \\
\hline Sample & All firms & \multicolumn{3}{|c|}{ All Foreign Multinationals } & \multicolumn{3}{|c|}{ European Foreign Multinationals } \\
\hline $\begin{array}{l}\text { Trust (region) } \\
\text { Trust measured in plant's region } \\
\text { of location }\end{array}$ & $\begin{array}{c}0.627^{* *} \\
(0.309)\end{array}$ & $\begin{array}{c}0.451 \\
(0.602)\end{array}$ & $\begin{array}{c}0.362 \\
(0.858)\end{array}$ & & $\begin{array}{c}0.131 \\
(1.999)\end{array}$ & & \\
\hline $\begin{array}{l}\text { Trust (country of origin) } \\
\text { Trust measured in firm's country } \\
\text { of origin }\end{array}$ & & & $\begin{array}{l}0.767 * * \\
(0.298)\end{array}$ & $\begin{array}{l}0.729 * * \\
(0.332)\end{array}$ & $\begin{array}{c}0.206 \\
(0.556)\end{array}$ & & \\
\hline $\begin{array}{l}\text { Bilateral trust } \\
\text { Trust of people from country of } \\
\text { origin for people in country of } \\
\text { location }\end{array}$ & & & & & $\begin{array}{c}1.711^{* *} \\
(0.721)\end{array}$ & $\begin{array}{l}2.025^{*} \\
(1.112)\end{array}$ & $\begin{array}{c}2.011 \\
(1.571)\end{array}$ \\
\hline $\begin{array}{l}\text { Plant Skills } \\
\text { \% Plant employees with a College } \\
\text { degree }\end{array}$ & $\begin{array}{c}0.083^{* * *} \\
(0.017)\end{array}$ & $\begin{array}{c}0.190 * * * \\
(0.031)\end{array}$ & $\begin{array}{c}0.189 * * * \\
(0.038)\end{array}$ & $\begin{array}{c}0.203^{* * *} \\
(0.040)\end{array}$ & $\begin{array}{c}0.161^{* *} \\
(0.076)\end{array}$ & $\begin{array}{c}0.228 * * \\
(0.109)\end{array}$ & $\begin{array}{c}0.228 * * * \\
(0.060)\end{array}$ \\
\hline $\begin{array}{l}\text { Firm Size } \\
\text { In(Firm Employment) }\end{array}$ & $\begin{array}{c}0.057 * * * \\
(0.022)\end{array}$ & $\begin{array}{c}0.024 \\
(0.036)\end{array}$ & $\begin{array}{c}0.025 \\
(0.033)\end{array}$ & $\begin{array}{c}0.022 \\
(0.033)\end{array}$ & $\begin{array}{c}0.070 \\
(0.101)\end{array}$ & $\begin{array}{c}0.049 \\
(0.127)\end{array}$ & $\begin{array}{c}0.049 \\
(0.075)\end{array}$ \\
\hline $\begin{array}{l}\text { Plant Employment } \\
\text { Plant employees as a \% of firm }\end{array}$ & $\begin{array}{c}0.104 * * * \\
(0.029)\end{array}$ & $\begin{array}{c}0.083 \\
(0.062)\end{array}$ & $\begin{array}{l}0.082^{* *} \\
(0.033)\end{array}$ & $\begin{array}{l}0.103^{* *} \\
(0.038)\end{array}$ & $\begin{array}{c}0.146 \\
(0.094)\end{array}$ & $\begin{array}{c}0.169 \\
(0.111)\end{array}$ & $\begin{array}{l}0.169 * * \\
(0.080)\end{array}$ \\
\hline $\begin{array}{l}\text { Foreign MNE } \\
\text { Dummy=1 if firm belongs to a } \\
\text { foreign multinational }\end{array}$ & $\begin{array}{c}0.154^{* * *} \\
(0.053)\end{array}$ & & & & & & \\
\hline $\begin{array}{l}\text { Domestic MNE } \\
\text { Dummy }=1 \text { if firm belongs to a } \\
\text { domestic multinational }\end{array}$ & $\begin{array}{c}0.018 \\
(0.037)\end{array}$ & & & & & & \\
\hline $\begin{array}{l}\text { First stage F-test } \\
\text { Instruments (Somatic dist. } \\
\text { Religious dist.) }\end{array}$ & & & & & & & 15.20 \\
\hline Observations & 3,660 & 866 & 866 & 866 & 282 & 282 & 282 \\
\hline Regional controls (2) & yes & yes & yes & yes & yes & - & - \\
\hline Industry dummies (21) & yes & yes & Yes & yes & yes & yes & yes \\
\hline Country dummies (12) & yes & yes & yes & yes & yes & yes & yes \\
\hline Other controls (60) & yes & yes & yes & yes & yes & yes & yes \\
\hline Country of origin controls (2) & no & no & yes & yes & yes & yes & yes \\
\hline $\begin{array}{l}\text { Regional dummies (105) } \\
\text { Country of origin dummies }\end{array}$ & no & no & no & yes & no & yes & yes \\
\hline $\begin{array}{l}\text { (25) } \\
\text { Clustering }\end{array}$ & $\begin{array}{c}\text { no } \\
\text { Region }\end{array}$ & $\begin{array}{c}\text { no } \\
\text { Region }\end{array}$ & $\begin{array}{c}\text { no } \\
\text { Cty origin }\end{array}$ & $\begin{array}{c}\text { no } \\
\text { Cty origin }\end{array}$ & $\begin{array}{c}\text { no } \\
\text { Cty origin } \\
\text { by location }\end{array}$ & $\begin{array}{l}\text { yes } \\
\text { Cty origin } \\
\text { by location }\end{array}$ & $\begin{array}{c}\text { yes } \\
\text { Cty origin } \\
\text { by location }\end{array}$ \\
\hline
\end{tabular}

Notes: * significant at $10 \%$; ** significant at 5\%; *** significant at $1 \%$. The dependent variable is the decentralization z-score index, measured by plant manager's degree of autonomy over hiring, investment, products and pricing. Column (1) includes all firms; Columns (2)(7) include only foreign multinationals. Estimation by OLS in columns (1)-(6) and IV in column (7). Instruments are "religious diversity" and "somatic distance" between each country pair. Standard errors (in parentheses) are clustered as noted: "cty origin by location" indicates clustering within each country origin by region of location cell. TRUST measures the percentage of individuals who agreed with the statement "most people can be trusted" in the region of firm's location or country of origin. BILATERAL TRUST measures the percentage of people from country of origin who report to "trust a lot" people living in the country of firm's location. "Other controls" include a dummy for whether the firm is publicly listed, a dummy for whether the CEO is on the same site as the plant ("CEO onsite") and "Noise controls" (these include 44 interviewer dummies, 6 dummies to control for the day of the week the interview took place, an interview reliability score, the manager's seniority and tenure, the duration of the interview, and 4 dummies for missing values in seniority, tenure, duration and reliability). Regional controls are GDP per capita and population in the region. Country of origin controls are GDP per capita and population. Weighted by the share of World Values Survey respondents in the region in the country. 
TABLE 3

FIRM SIZE AND TRUST

\begin{tabular}{|c|c|c|c|c|c|}
\hline $\begin{array}{l}\text { Dependent variable: } \\
\text { In(mean employees per firm) }\end{array}$ & (1) & (2) & (3) & (4) & (5) \\
\hline Sample: & $\begin{array}{c}100+ \\
\text { employees }\end{array}$ & $\begin{array}{c}100+ \\
\text { employees }\end{array}$ & $\begin{array}{c}50+ \\
\text { employees }\end{array}$ & $\begin{array}{c}25^{+} \\
\text {employees }\end{array}$ & $\begin{array}{c}\text { All } \\
\text { employees }\end{array}$ \\
\hline Trust (region) & $2.216^{* * *}$ & $1.851 * *$ & $1.713^{*}$ & $1.597^{*}$ & $1.540^{*}$ \\
\hline Trust measured in firm's region of location & $(0.478)$ & $(0.889)$ & $(0.874)$ & $(0.857)$ & $(0.858)$ \\
\hline Rule of Law (country) & $0.476^{* * *}$ & & & & \\
\hline$(-2.5=$ low, $2.5=$ high $)$ & $(0.079)$ & & & & \\
\hline Observations & 110 & 110 & 110 & 110 & 110 \\
\hline Regional controls & no & yes & yes & yes & yes \\
\hline Country dummies & no & yes & yes & yes & yes \\
\hline
\end{tabular}

Notes: * significant at $10 \%$; ** significant at 5\%; *** significant at $1 \%$. The dependent variable is $\ln ($ mean employees per firm) in the population of all manufacturing firms in that country region. SAMPLE reports the size cut off for inclusion in the sample - for example in column (1) all firms with 100+ employees were used to calculate the log mean employees per firm. TRUST measures the percentage of individuals in the region's country of location who agreed with the statement "most people can be trusted". RULE OF LAW measures the extent to which agents have confidence in and abide by the rules of society, and in particular the quality of contract enforcement, the police, and the courts, as well as the likelihood of crime and violence in the firm's country of location. The index is compiled by the World Bank (Kauffman et al, 2007), and ranges between -2.5 and 2.5. Regional controls are GDP per capita, population in the region and \% of employees with a degree. Standard errors are clustered as detailed in the table. 
TABLE 4

IMPLIED INDUSTRY DECENTRALIZATION

Dependent variable: implied industry decentralization

(1)

(2)

(3)

Trust (region)

$0.100 * *$

$0.099 * * *$

0.095

Trust measured in plant's region of location

(0.029)

$(0.031)$

$0.027^{* *}$

Rule of Law (country)

(0.014)

(-2.5=low, 2.5=high)

\begin{tabular}{lccc} 
Observations & 98 & 98 & 98 \\
\hline Regional controls & yes & yes & yes \\
Country dummies & no & no & yes \\
& & & \\
\hline \hline
\end{tabular}

Notes: * significant at $10 \%$; ** significant at $5 \%$; *** significant at $1 \%$. The dependent variable is “implied industry decentralization”, measured as the industry share of employment in each region by SIC2 multiplied by that decentralization value for that SIC2 industry in the UK. The regression sample is all countries except the UK. Hence, a high value indicates a large share of employment in the region in industries which are decentralized in the UK. Estimation by OLS with heteroskedasticity robust standard errors. TRUST measures the percentage of individuals in the region's country of location who agreed with the statement "most people can be trusted". RULE OF LAW measures the extent to which agents have confidence in and abide by the rules of society, and in particular the quality of contract enforcement, the police, and the courts, as well as the likelihood of crime and violence in the firm's country of location. The index is compiled by the World Bank (Kauffman et al, 2007), and ranges between -2.5 and 2.5. Regional controls are GDP per capita, population in the region and \% of employees with a degree. 


\section{TABLE 5 \\ RELIGION AND DECENTRALIZATION}

\begin{tabular}{|c|c|c|c|c|c|}
\hline $\begin{array}{l}\text { Dependent variable: } \\
\text { Decentralization }\end{array}$ & $\begin{array}{l}(1) \\
\text { OLS }\end{array}$ & $\begin{array}{l}(2) \\
\text { OLS }\end{array}$ & $\begin{array}{l}\text { (3) } \\
\text { OLS }\end{array}$ & $\begin{array}{l}\text { (4) } \\
\text { IV }\end{array}$ & $\begin{array}{l}\text { (5) } \\
\text { OLS }\end{array}$ \\
\hline & & All Firms & & $\begin{array}{l}\text { Fr, Ger, Pol, } \\
\text { Sw \& UK }\end{array}$ & $\begin{array}{c}\text { Foreign } \\
\text { Multinationals }\end{array}$ \\
\hline Hierarchical (region) & $-0.484^{* * *}$ & $-0.268 * *$ & $-0.494 * *$ & $-0.764 * * *$ & \\
\hline $\begin{array}{l}\text { \% of Catholics, Muslims and Orthodox in } \\
\text { plant's region of location }\end{array}$ & $(0.163)$ & $(0.124)$ & $(0.199)$ & $(0.258)$ & \\
\hline $\begin{array}{l}\text { Rule of Law (country) } \\
(-2.5=\text { low, } 2.5=\text { high })\end{array}$ & & $\begin{array}{l}0.292 * * * \\
(0.063)\end{array}$ & & & \\
\hline $\begin{array}{l}\text { Hierarchical (country of origin) } \\
\% \text { of Catholics, Muslims and Orthodox in } \\
\text { plant's country of origin }\end{array}$ & & & & & $\begin{array}{c}-0.381 * * \\
(0.155)\end{array}$ \\
\hline Trust (region) & & & $0.797 * *$ & 0.605 & \\
\hline Trust measured in plant's region of location & & & $(0.327)$ & $(0.381)$ & \\
\hline Plant Skills & & & $0.085 * * *$ & $0.085 * * *$ & $0.207 * * *$ \\
\hline \% Plant employees with a College degree & & & $(0.015)$ & $(0.018)$ & $(0.041)$ \\
\hline Firm Size & & & $0.052 * *$ & $0.097 * * *$ & 0.019 \\
\hline In(Firm employment) & & & $(0.022)$ & $(0.035)$ & $(0.033)$ \\
\hline Plant Employment & & & $0.090 * * *$ & $0.119 * *$ & $0.097 * *$ \\
\hline Plant employees as a \% of firm & & & $(0.030)$ & $(0.056)$ & $(0.037)$ \\
\hline Foreign Multinational & & & $0.156^{* * *}$ & 0.115 & \\
\hline $\begin{array}{l}\text { Dummy=1 if firm belongs to a foreign } \\
\text { multinational }\end{array}$ & & & $(0.057)$ & $(0.080)$ & \\
\hline Domestic Multinational & & & 0.021 & 0.083 & \\
\hline firm belongs to a domestic multinational & & & $(0.040)$ & $(0.064)$ & \\
\hline $\begin{array}{l}\text { First stage F-test } \\
\text { Instrument (1) }\end{array}$ & & & & $\begin{array}{c}50.36 \\
\text { Reformation }\end{array}$ & \\
\hline Observations & 3,660 & 3,660 & 3,660 & 1,541 & 866 \\
\hline Regional controls (2) & yes & yes & yes & yes & yes \\
\hline Industry dummies (112) & no & no & yes & yes (21) & yes (21) \\
\hline Country dummies (12) & no & no & yes & no & yes \\
\hline Other controls (60) & no & no & yes & yes (16) & yes \\
\hline Country of origin controls (2) & no & no & no & no & yes \\
\hline Regional dummies (105) & no & no & no & no & yes \\
\hline Clustering & Region & Region & Region & Region & $\begin{array}{l}\text { Country of } \\
\text { origin }\end{array}$ \\
\hline \multicolumn{6}{|c|}{$\begin{array}{l}\text { Notes: * significant at } 10 \% \text {; ** significant at } 5 \% \text {; ** significant at } 1 \% \text {. Estimation by OLS in all columns except (4). The dependent } \\
\text { variable is the decentralization z-score index, measured by plant manager's degree of autonomy over hiring, investment, products and } \\
\text { pricing. Standard errors clustered as noted in the table. IV estimation in column (4) uses whether the region accepted the Reformation as } \\
\text { the instrument, covering France, Germany, Poland, Sweden and the UK. HIERARCHICAL is the percentage of Catholics, Muslims and } \\
\text { Orthodox living in the firm's region of location, or country of origin. RULE OF LAW measures the extent to which agents have } \\
\text { confidence in and abide by the rules of society, and in particular the quality of contract enforcement, the police, and the courts, as well as } \\
\text { the likelihood of crime and violence in the firm's country of location. The index is compiled by the World Bank (Kauffman et al, 2007), } \\
\text { and ranges between }-2.5 \text { and 2.5. TRUST measures the percentage of individuals who agreed with the statement "most people can be } \\
\text { trusted" in the firm's region of location. "Other controls" include a dummy for whether the firm is publicly listed, a dummy for whether } \\
\text { the CEO is on the same site as the plant ("CEO onsite") and "Noise controls" (these include } 44 \text { interviewer dummies, } 6 \text { dummies to } \\
\text { control for the day of the week the interview took place, an interview reliability score, the manager's seniority and tenure, the duration of } \\
\text { the interview, and } 4 \text { dummies for missing values in seniority, tenure, duration and reliability). In column (4) the noise controls do not } \\
\text { include the interviewer dummies. Regional controls are GDP per capita and population in the region (included in all columns). Country } \\
\text { of origin controls are GDP per capita and population. Weighted by the share of World Values Survey respondents in the region in the } \\
\text { country. }\end{array}$} \\
\hline
\end{tabular}


TABLE 6

COMPETITION AND DECENTRALIZATION

\begin{tabular}{|c|c|c|c|c|c|c|}
\hline $\begin{array}{l}\text { Dependent variable: } \\
\text { decentralization }\end{array}$ & (1) & (2) & (3) & (4) & (5) & (6) \\
\hline $\begin{array}{l}\text { Import Penetration } \\
\text { ( } 3 \text { years lagged) }\end{array}$ & $\begin{array}{c}0.131^{* * * *} \\
(0.050)\end{array}$ & $\begin{array}{c}0.156 * * \\
(0.071)\end{array}$ & & & & \\
\hline $\begin{array}{l}\text { Industry Lerner Competition index } \\
\text { ( } 3 \text { years lagged) }\end{array}$ & & & $\begin{array}{c}5.705^{* * *} \\
(0.850)\end{array}$ & $\begin{array}{c}2.937 * * * \\
(1.056)\end{array}$ & & \\
\hline $\begin{array}{l}\text { Number of Competitors } \\
(0=\text { none, } 1=\text { between } 1 \text { and } 4,2=\text { more than } 4)\end{array}$ & & & & & $\begin{array}{c}0.122 * * * \\
(0.036)\end{array}$ & $\begin{array}{c}0.099 * * * \\
(0.038)\end{array}$ \\
\hline Trust (region) & & $1.103^{* *}$ & & $0.719 * *$ & & $0.815^{* *}$ \\
\hline Trust measured in plant's region of location & & $(0.469)$ & & $(0.346)$ & & $(0.343)$ \\
\hline Hierarchical (region) & & -0.344 & & $-0.490 * *$ & & $-0.514 * *$ \\
\hline $\begin{array}{l}\text { \% of Catholics, Muslims and Orthodox in } \\
\text { firm's region of location }\end{array}$ & & $(0.220)$ & & $(0.200)$ & & $(0.213)$ \\
\hline Plant Skills & & $0.077 * * *$ & & $0.084 * * *$ & & $0.085^{* * *}$ \\
\hline \% Plant employees with a College degree & & $(0.019)$ & & $(0.018)$ & & $(0.018)$ \\
\hline Firm Size & & $0.075^{* * *}$ & & $0.053^{* *}$ & & $0.050 * *$ \\
\hline Ln(Firm Employment) & & $(0.028)$ & & $(0.022)$ & & $(0.021)$ \\
\hline Plant Employment & & $0.129 * * *$ & & $0.090 * * *$ & & $0.088 * * *$ \\
\hline Plant employees as a \% of firm & & $(0.027)$ & & $(0.026)$ & & $(0.024)$ \\
\hline Foreign Multinational & & $0.187 * * *$ & & $0.150 * * *$ & & $0.161^{* * *}$ \\
\hline $\begin{array}{l}\text { Dummy }=1 \text { if firm belongs to a foreign } \\
\text { multinational }\end{array}$ & & $(0.054)$ & & $(0.047)$ & & $(0.047)$ \\
\hline Domestic Multinational & & 0.043 & & 0.018 & & 0.022 \\
\hline $\begin{array}{l}\text { Dummy= } 1 \text { if firm belongs to a domestic } \\
\text { multinational }\end{array}$ & & $(0.063)$ & & $(0.053)$ & & $(0.049)$ \\
\hline Observations & 2,508 & 2,508 & 3,660 & 3,660 & 3,660 & 3,600 \\
\hline Regional controls (2) & no & yes & no & yes & no & yes \\
\hline Industry dummies (112) & no & yes & no & yes & no & yes \\
\hline Country dummies (12) & no & yes & no & yes & no & yes \\
\hline Other controls (60) & no & yes & no & yes & no & yes \\
\hline Clustering & $\begin{array}{l}\text { Country } \\
* \text { ISIC2 }\end{array}$ & $\begin{array}{l}\text { Country } \\
* \text { ISIC2 }\end{array}$ & $\begin{array}{l}\text { Country } \\
* \text { SIC3 }\end{array}$ & $\begin{array}{l}\text { Country } \\
* \text { SIC3 }\end{array}$ & $\begin{array}{l}\text { None } \\
\text { (robust) }\end{array}$ & $\begin{array}{l}\text { None } \\
\text { (robust) }\end{array}$ \\
\hline
\end{tabular}

Notes: * significant at 10\%; ** significant at 5\%; *** significant at 1\%. The dependent variable is the decentralization $\mathrm{z}$-score index, measured by plant manager's degree of autonomy over hiring, investment, products and pricing. Estimation by OLS with robust standard errors in parentheses. Standard errors are clustered at the same level as the relevant competition measure (as noted in the table). "Lerner" is the median of 1-(profit/sales) in the three digit industry in the country of location averaged between 2000 and 2003 (computed from Amadeus and Oriana). Import Penetration is the ratio of imports over production in the two digit industry (ISIC) in the country of location averaged between 1999 and 2003 (computed from OECD STAN Database). "Number of competitors” is taken from the survey and is the number of rivals the manager perceives he faces. "Other controls" include a dummy for whether the firm is publicly listed, a dummy for whether the CEO is on the same site as the plant ("CEO onsite") and "Noise controls" (these include 44 interviewer dummies, 6 dummies to control for the day of the week the interview took place, an interview reliability score, the manager's seniority and tenure, the duration of the interview, and 4 dummies for missing values in seniority, tenure, duration and reliability). TRUST measures the percentage of individuals who agreed with the statement "most people can be trusted" in the firm's region of location. Regional controls are GDP per capita and population in the region. 
TABLE 7

DECENTRALIZATION REGRESSION ROBUSTNESS CHECKS

\begin{tabular}{|c|c|c|c|c|c|c|c|c|c|c|}
\hline Sample/Experiment: & All & $\begin{array}{c}\text { Single } \\
\text { Plant } \\
\text { Firms }\end{array}$ & $\begin{array}{l}\text { Multi Plant } \\
\text { Firms }\end{array}$ & $\begin{array}{c}\text { CEO on } \\
\text { site }\end{array}$ & $\begin{array}{l}\text { CEO not } \\
\text { on site }\end{array}$ & $\begin{array}{c}\text { Between } \\
250 \text { and } \\
5000 \\
\text { employees }\end{array}$ & $\begin{array}{c}\text { Privately } \\
\text { held firms }\end{array}$ & $\begin{array}{c}\text { OECD } \\
\text { countries }\end{array}$ & $\begin{array}{l}\text { Domestic } \\
\text { Firms }\end{array}$ & Multinationals \\
\hline $\begin{array}{l}\text { Dependent variable: } \\
\text { decentralization }\end{array}$ & (1) & (2) & (3) & (4) & (5) & (6) & (7) & (8) & (9) & (10) \\
\hline Number of Competitors & $\begin{array}{c}0.099 * * * \\
(0.031)\end{array}$ & $\begin{array}{c}0.035 \\
(0.054)\end{array}$ & $\begin{array}{c}0.167^{* * *} \\
(0.046)\end{array}$ & $\begin{array}{c}0.101^{* *} \\
(0.044)\end{array}$ & $\begin{array}{c}0.108 * * \\
(0.053)\end{array}$ & $\begin{array}{c}0.122 * * \\
(0.056)\end{array}$ & $\begin{array}{c}0.092 * * \\
(0.036)\end{array}$ & $\begin{array}{c}0.090 * * \\
(0.035)\end{array}$ & $\begin{array}{l}0.098^{*} \\
(0.052)\end{array}$ & $\begin{array}{l}0.093^{*} \\
(0.050)\end{array}$ \\
\hline Trust (region) & $\begin{array}{c}0.815^{* *} \\
(0.327)\end{array}$ & $\begin{array}{c}0.326 \\
(0.472)\end{array}$ & $\begin{array}{c}1.256^{* * * *} \\
(0.408)\end{array}$ & $\begin{array}{c}0.380 \\
(0.387)\end{array}$ & $\begin{array}{c}1.339 * * * \\
(0.492)\end{array}$ & $\begin{array}{l}0.825^{*} \\
(0.420)\end{array}$ & $\begin{array}{c}0.878^{* *} \\
(0.352)\end{array}$ & $\begin{array}{c}1.324^{* * *} \\
(0.434)\end{array}$ & $\begin{array}{l}0.817^{*} \\
(0.427)\end{array}$ & $\begin{array}{l}0.902 * \\
(0.514)\end{array}$ \\
\hline Hierarchical (region) & $\begin{array}{c}-0.514^{* *} \\
(0.207)\end{array}$ & $\begin{array}{c}-0.484 \\
(0.467)\end{array}$ & $\begin{array}{c}-0.556 * * * \\
(0.188)\end{array}$ & $\begin{array}{c}-0.424^{*} \\
(0.245)\end{array}$ & $\begin{array}{c}-0.496^{*} \\
(0.288)\end{array}$ & $\begin{array}{c}-0.581^{* *} \\
(0.230)\end{array}$ & $\begin{array}{c}-0.552 * \\
(0.297)\end{array}$ & $\begin{array}{c}-0.543^{* *} \\
(0.220)\end{array}$ & $\begin{array}{l}-0.487 \\
(0.302)\end{array}$ & $\begin{array}{c}-0.515^{* *} \\
(0.227)\end{array}$ \\
\hline Observations & 3,660 & 1,462 & 2,198 & 2,280 & 1,380 & 2,094 & 3,112 & 2,723 & 1,974 & 1,686 \\
\hline
\end{tabular}

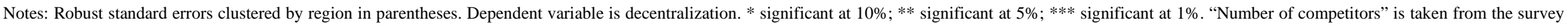

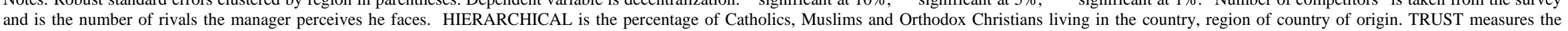

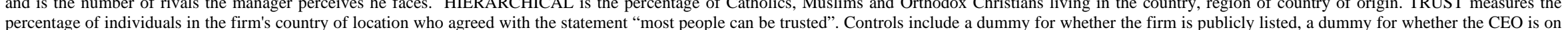

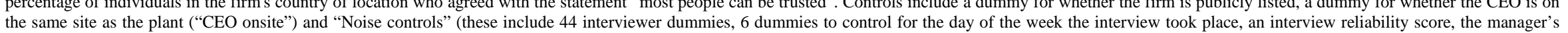

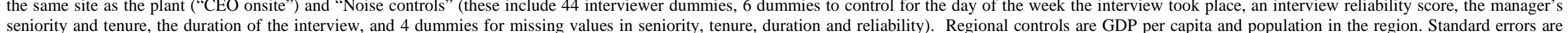
seniority and tenure, the duration of the interview, and 4 dummies for missing values in seniority, tenure, duration and reliability). Regional controls are GDP per capita and population in the region. Standard errors are
clustered as detailed in the table. All columns weighted by the share of World Values Survey respondents in the region in the country. All columns include a full set of country dummies (12) and industry dummies ( 112$)$. 
TABLE 7

DECENTRALIZATION REGRESSION ROBUSTNESS CHECKS (CONTINUED)

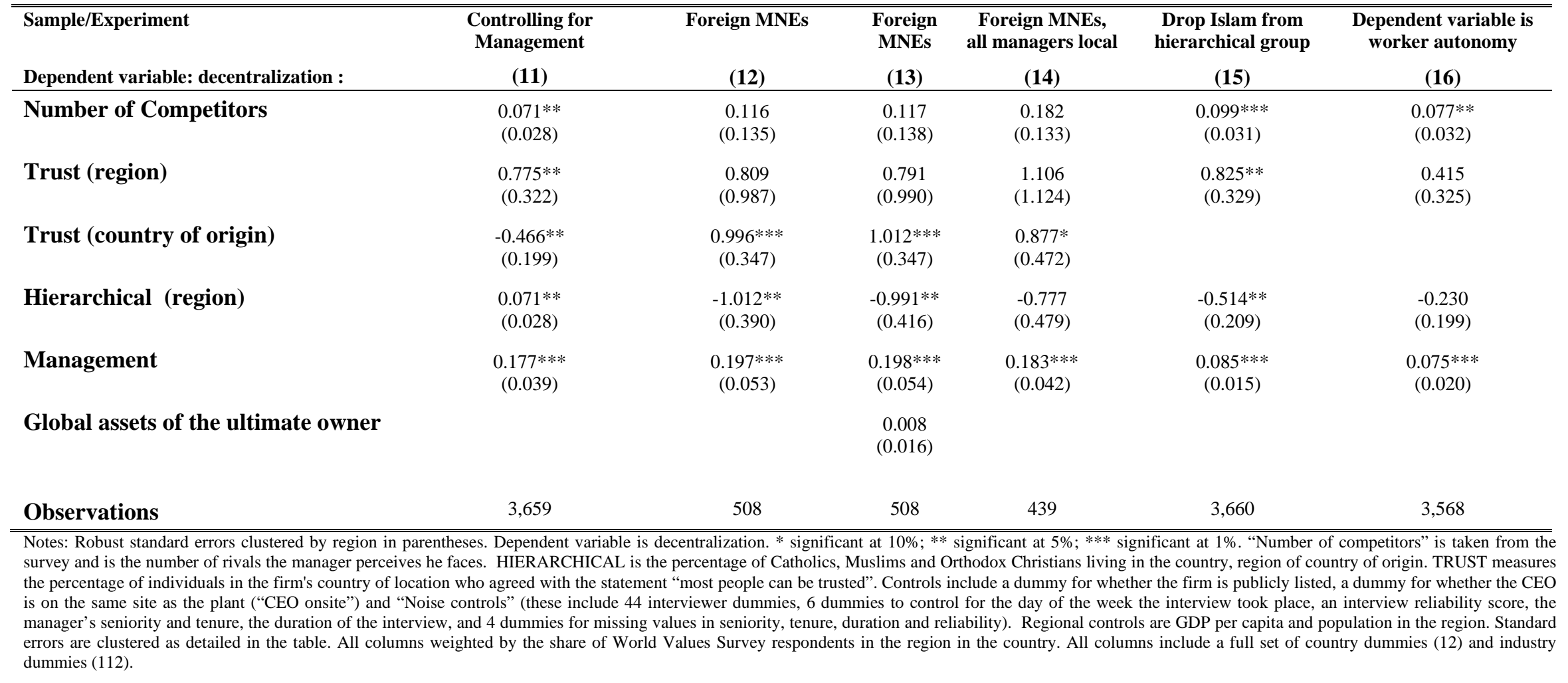


TABLE 8

DECENTRALIZATION AND FIRM-LEVEL PRODUCTIVITY

\begin{tabular}{|c|c|c|c|c|c|}
\hline $\begin{array}{l}\text { Dependent variable: } \\
\text { In(Sales) }\end{array}$ & (1) & (2) & (3) & (4) & (5) \\
\hline $\begin{array}{l}\text { Decentralization } \\
\text { Firm level decentralization z-score }\end{array}$ & $\begin{array}{c}0.100^{* * *} \\
(0.015)\end{array}$ & $\begin{array}{l}0.023^{*} \\
(0.014)\end{array}$ & $\begin{array}{c}0.046^{* *} \\
(0.021)\end{array}$ & & \\
\hline $\begin{array}{l}\text { Ln(Employment) } \\
\text { In(number of employees) }\end{array}$ & $\begin{array}{c}0.594 * * * \\
(0.023)\end{array}$ & $\begin{array}{c}0.665^{* * *} \\
(0.021)\end{array}$ & $\begin{array}{c}0.705^{* * *} \\
(0.031)\end{array}$ & $\begin{array}{c}0.445^{* * *} \\
(0.076)\end{array}$ & $\begin{array}{c}0.438 * * * \\
(0.074)\end{array}$ \\
\hline $\begin{array}{l}\text { Ln(Capital) } \\
\text { In (net tangible fixed assets) }\end{array}$ & $\begin{array}{c}0.406^{* * *} \\
(0.017)\end{array}$ & $\begin{array}{c}0.336 * * * \\
(0.016)\end{array}$ & $\begin{array}{c}0.297 * * * \\
(0.022)\end{array}$ & $\begin{array}{c}0.373^{* * *} \\
(0.044)\end{array}$ & $\begin{array}{c}0.390^{* * * *} \\
(0.043)\end{array}$ \\
\hline $\begin{array}{l}\text { Ln(Skills) } \\
\text { In (\% employees with a degree) }\end{array}$ & & $\begin{array}{c}0.060 * * * \\
(0.013)\end{array}$ & $\begin{array}{c}0.049 * * \\
(0.019)\end{array}$ & & \\
\hline $\begin{array}{l}\text { Ln (IT) } \\
\text { In (number of PCs per employee) }\end{array}$ & & & $\begin{array}{c}0.126 * * * \\
(0.024)\end{array}$ & $\begin{array}{c}0.073^{* * *} \\
(0.021)\end{array}$ & $\begin{array}{c}0.070^{* * *} \\
(0.021)\end{array}$ \\
\hline $\begin{array}{l}\text { Decentralization*In(IT) } \\
\text { Decentralization and IT interaction }\end{array}$ & & & $\begin{array}{c}0.047 * * * \\
(0.017)\end{array}$ & $\begin{array}{l}0.032 * \\
(0.017)\end{array}$ & $\begin{array}{c}0.035^{* *} \\
(0.017)\end{array}$ \\
\hline $\begin{array}{l}\text { Decentralization*In(Capital) } \\
\text { Decentralization and Capital interaction }\end{array}$ & & & & & $\begin{array}{l}-0.046^{*} \\
(0.026)\end{array}$ \\
\hline $\begin{array}{l}\text { Firms } \\
\text { Observations }\end{array}$ & $\begin{array}{c}1,674 \\
11,690\end{array}$ & $\begin{array}{c}1,674 \\
11,690\end{array}$ & $\begin{array}{c}713 \\
3,509\end{array}$ & $\begin{array}{c}713 \\
3,509\end{array}$ & $\begin{array}{c}713 \\
3,509\end{array}$ \\
\hline $\begin{array}{l}\text { Country and industry controls (122) } \\
\text { Other controls (62) } \\
\text { Firm fixed effects }\end{array}$ & $\begin{array}{l}\text { no } \\
\text { no } \\
\text { no }\end{array}$ & $\begin{array}{c}\text { yes } \\
\text { yes } \\
\text { no }\end{array}$ & $\begin{array}{c}\text { yes } \\
\text { yes } \\
\text { no }\end{array}$ & $\begin{array}{l}\text { yes } \\
\text { yes } \\
\text { yes }\end{array}$ & $\begin{array}{l}\text { yes } \\
\text { yes } \\
\text { yes }\end{array}$ \\
\hline
\end{tabular}

Notes: * significant at $10 \%$; ** significant at $5 \%$; ** significant at $1 \%$. Estimation by OLS with robust standard errors in parentheses. The dependent variable is log (sales). DECENTRALIZATION z-score index, measured by the degree of plant manager's autonomy over hiring, investment, products and pricing. Standard errors are clustered at the firm level. "Country and industry" controls include a full set of country and three digit industry dummies. OTHER CONTROLS includes a full set of noise controls (the day of the week the interview took place, an interview reliability score, the manager's seniority and tenure, the duration of the interview, and 4 dummies for missing values in seniority, tenure, duration and reliability) and controls for accounts consolidation status and public listing. 


\section{DATA APPENDIX}

\section{A1. Firm-level Accounting Databases}

Our sampling frame was based on the Bureau van Dijk (BVD) Amadeus dataset for Europe (France, Germany, Greece, Italy, Poland, Portugal and the U.K.), on BVD Icarus for the US, on CMIE Firstsource dataset for India, and on the BVD Oriana dataset for China and Japan. These databases all provide sufficient information on companies to conduct a stratified telephone survey (company name, address and a size indicator). These databases also typically have accounting information on employment, sales and capital. Apart from size, we did not insist on having accounting information to form the sampling population, however.

Amadeus and Firstsource are constructed from a range of sources, primarily the National registries of companies (such as Companies House in the UK and the Registry of Companies in India). Icarus is constructed from the Dun \& Bradstreet database, which is a private database of over 5 million US trading locations built up from credit records, business telephone directories and direct research. Oriana is constructed from Huaxia credit in China and Teikoku Database in Japan, covering all public and all private firms with one of the following: 150 or more employees, 10 million US\$ of sales or 20 million US\$ of assets.

In addition to using these accounting databases for the sampling frame we also use them to conduct the analysis of firm size in Table 3. Since our measure of decentralization focuses on the delegation of power between the company headquarters and the plant manager, firm size is the appropriate concept to use rather than plant size. Census data do not report firm sizes on a consistent basis across which is why we use the BVD and CMIE datasets. We discuss issues of representativeness below in sub-section $\mathrm{A} 2$.

\section{A2. The Organizational Survey}

In every country the sampling frame for the organization survey was all firms with a manufacturing primary industry code with between 100 and 5,000 employees on average over the most recent three years of data (typically 2002 to 2004) ${ }^{5}$. In Japan and China we used all manufacturing firms with 150 to 5000 employees since Oriana only samples firms with over 150 employees, while in Portugal we supplemented the sample with firms with 75 to 100 employees. ${ }^{52}$ We checked the results by conditioning on common size bands (above 150 in all countries).

\footnotetext{
${ }^{51}$ In the US only the most recent year of employment is provided. In India employment is not reported for private firms, so for these companies we used forecast employment, predicted from their total assets (which are reported) using the coefficients from regressing ln(employees) on log (assets) for public firms.

${ }^{52}$ Note that the Oriana database does include firms with less than 150 employees if they meet the sales or assets criteria, but we excluded this to avoid using a selected sample.
} 
Interviewers were each given a randomly selected list of firms from the sampling frame. This should therefore be representative of medium sized manufacturing firms. The size of this sampling frame by country is shown in Table A4, together with information on firm size. Looking at Table A4 two points are worth highlighting on the sampling frame. First, the size of the sampling frame appears broadly proportional to the absolute size of each country's manufacturing base, with China, the US and India having the most firms and Sweden, Greece and Portugal the fewest ${ }^{53}$. Second, China has the largest firms on average, presumably reflecting both the higher size cut-off for its sampling frame (150 employees versus 100 employees for other countries) and also the presence of many current and ex state-owned enterprises (11\% in the survey are still Government owned). When we condition on the sample of firms with more than 150 employees in all countries, median employment for Chinese firms is still relatively high, but lower than the US, UK and Sweden. Third, Greece and India have a much higher share of publicly quoted firms then the other countries, with this presumably reflecting their more limited provision of data on privately held firms. Because of this potential bias across countries will control for firm size and listing status in all the main regressions.

In addition to randomly surveying from the sampling frame described above we also resurveyed the firms we interviewed in the 2004 survey wave used in Bloom and Van Reenen (2007). This was a sample of 732 firms from France, Germany, the UK and the US, with a manufacturing primary industry code and 50 to 10,000 employees (on average between 2000 and 2003). This sample was drawn from the Amadeus dataset for Europe and the Compustat dataset for the U.S. Only companies with accounting data were selected. So, for the UK and France this sampling frame was very similar to the 2006 sampling frame. For Germany it is more heavily skewed towards publicly quoted firms since smaller privately held firms do not report balance sheet information. For the US it comprised only publicly quoted firms. As a result when we present results we always include controls for firm size. As a robustness test we drop the firms that were resurveyed from 2004. These resurveyed firms were randomly distributed among the relevant country interviewers.

\section{The Representativeness of the Sampling Frame}

The accounting databases are used to generate our organizational survey and also used directly in the analysis of the firm size distribution in Table 3. How does this compare to Census data? Table A5 compares the number of employees for different size bands from our sample with the figures for the corresponding manufacturing populations obtained from national Census Bureau data from each of the twelve countries. Unfortunately, figures for the population distributions are not available from every country in the same format, but all our countries do report the number of employees in enterprises with over 50 or more employees (except the US where the threshold is 20 or 100) so we report this.

Note that there are several reasons for mismatch between Census data and firm level accounts. First, even though we only use unconsolidated firm accounts, employment may included some jobs in overseas branches. Second, the time of when employment is recorded in a Census year will

\footnotetext{
${ }^{53}$ The size of the manufacturing sector can be obtained from http://laborsta.ilo.org/, a database maintained by ILO. Indian data can be obtained from Indiastat, from the "Employment in Industry" table.
} 
differ from that recorded in firm accounts (see base of each column in Table A5). Third, the precise definition of "enterprise" in the Census may not correspond to the "firm" in company accounts (see notes in table for exact definitions). Fourth, we keep firms whose primary industry is manufacturing whereas Census data includes only plants whose primary industry code is manufacturing. Fifth, there may be duplication of employment in accounting databases due to the treatment of consolidated accounts ${ }^{54}$. Finally, reporting of employment is not mandatory for the accounts of all firms in all countries. This was particularly a problem for Indian and Japanese firms, so for these countries we imputed the missing employment numbers using a sales regression.

Despite these potential differences, the broad picture that from Table A5 is that in eight countries the sample matches up reasonably with the population of medium sized manufacturing firms (being within $17 \%$ above or below the Census total employment number). This suggests our sampling frame covers near to the population of all firms for most countries.

In two countries the coverage from accounting databases underestimates the aggregate: the Swedish data covers only $62 \%$ of Census data and the Portuguese accounting database covers $72 \%$. This is due to incomplete coverage in ORBIS of these smaller nations. In the US and Japan the accounting databases appears to overestimate the employment of manufacturing firms compared to Census data, by about 36\%. We think this is due to some double counting of the employment of subsidiaries due to imperfect recording of the consolidation markers in Japanese and US accounts.

These issues will be a problem if our sampling frame is non-randomly omitting firms - for example under-representing smaller firms - because it would bias our cross-country comparisons. We try a couple of approaches to try and address this. First, in almost all the tables of results we include country fixed-effects to try to control for any differences across countries in sample selection bias. Hence, our key results are identified by within country and region variation. Second, in our quantification analysis (sub-section VI.C) when we compare across countries we control for size, public listing status and industry. This should help to condition on the types of factors that lead to under/over sampling of firms. Since these factors explain only a limited share of cross country variation in decentralization this suggests this differential sampling bias is not likely to be particularly severe. Finally, we also present experiments where we drop the four possibly problematic countries (Japan, Portugal, Sweden and the US) from the analysis to show that the results are robust. In the specification of column (2) in Table 3 the coefficient on trust actually rose to 2.048 (standard error $=0.961$ ) even though we now have only 81 regions.

\section{The Survey Response Rate}

As shown in Table A6 of the firms we contacted $44.9 \%$ took part in the survey: a high success rate given the voluntary nature of participation. Of the remaining firms $16.8 \%$ refused to be surveyed, while the remaining $38.3 \%$ were in the process of being scheduled when the survey ended.

\footnotetext{
${ }^{54}$ Table A5 is built omitting all consolidated accounts to avoid duplications. Still, for some companies the consolidated accounts marker is sometimes missing so that duplications might still be present causing a "double counting” problem.
} 
The reason for this high share of 'scheduling in progress' firms was the need for interviewers to keep a portfolio of firms who they cycle though when trying to set up interviews. Since interviewers only ran an average of 2.8 interviews a day the majority of their time was spent trying to contact managers to schedule future interviews. For scheduling it was efficient for interviewers to keep a stock of between 100 to 500 firms to cycle through. The optimal level of this stock varied by the country - in the US and UK many managers operated voicemail, so that large stocks of firms were needed. In Japan after two weeks the team switched from working Japanese hours (midnight to 8am) to Japanese afternoons and UK morning (4am till midday), which left large stocks of contacted firms in Japan. ${ }^{55}$ In Continental Europe, in contrast, managers typically had personnel assistants rather than voicemail, who wanted to see Government endorsement materials before connecting with the managers. So each approach was more time consuming, requiring a smaller stock of firms.

The ratio of successful interviews to rejections (ignoring 'scheduling in progress') is above 1 in every country. Hence, managers typically agreed to the survey proposition when interviewers were able to connect with them. This agreement ratio is lowest in China and Japan. There were two reasons for this: first, the Chinese and Japanese firms did appear to be genuinely more willing to refuse to be interviewed; and second, the time-zone meant that our interviewers could not run talk during the Chinese or Japanese morning; which sometimes led to rejections if managers were too busy to talk in the afternoon.

Table A7 analyses the probability of being interviewed. ${ }^{56}$ In all columns, we compare the probability of running an interview conditional on contacting the firm, so including rejections and 'scheduling in progress' firms in the baseline. The decision to accept is uncorrelated with revenues per worker, firm age and listed status. The probability of being interviewed is also uncorrelated with the average level of trust and the percentage of hierarchical religions in the region. Large firms and multinationals did appear to be more predisposed to agree to be interviewed, although the size of this effect if not large - multinationals were about 11 percentage points more likely to agree to the interview and firms about 10 percentage points more likely for a doubling in size. Firms that were contacted earlier on in the survey were also significantly more likely to end up being interviewed, with firms contacted at the beginning of the survey over 8 percentage points more likely to be interviewed than those contacted towards the end ( 3 months later). The reason is that firms contacted early on in the survey were subsequently contacted many more times as interviewers cycled through their stocks of 'scheduling in progress firms'. Finally, compared to the US, France, Germany, Greece, India, Italy, Poland, Portugal and Sweden had significantly higher conditional acceptance rate - while China had a significantly lower acceptance rate. Column (2) shows that the likelihood of a contacted firm eventually being interviewed is also uncorrelated with return on capital employed, a basic profits measure.

\footnotetext{
${ }^{55}$ After two weeks of the Japanese team working midnight to 8am it became clear this schedule was not sustainable due to the unsociability of the hours, with one of the Japanese interviewers quitting. The rest of the team then switched to working 4am until noon.

${ }^{56}$ Note this sample is smaller than the total survey sample because some firms do not report data for certain explanatory variables, for example US private firms do not report sales.
} 
So, in summary, respondents were not significantly more productive or profitable than nonresponders. Firms contacted earlier on in the survey process were more likely to end up being interviewed. Respondents did tend to be slightly larger and more likely to be a multinational subsidiary, but were not more likely to be stock-market listed or older. Chinese and Japanese firms less likely to respond and European firms more likely to respond. Note, however, that we address this potential source of bias including in all regressions controls for size, multinational status and country dummies.

\section{Firm-level variables}

Our firm accounting data on sales, employment, capital, profits, shareholder equity, long-term debt, market values (for quoted firms) and wages (where available) came from BVD Amadeus dataset for Europe (France, Germany, Greece, Italy, Poland, Portugal and the U.K.), on BVD Icarus for the US, on CMIE Firstsource dataset for India, and on the BVD Oriana dataset for China and Japan.

BVD and CMIE also have extensive information on ownership structure, so we can use this to identify whether the firm was part of a multinational enterprise. We also asked specific questions on the multinational status of the firm (whether it owned plants aboard and the country where the parent company is headquartered) to be able to distinguish domestic multinationals from foreign multinationals.

We collected many variables through our survey including information on plant size, skills, organization, etc. as described in the main text. We asked the manager to estimate how many competitors he thought he faced (top-coded at 10 or more) which was used to construct the firmlevel competition variable (see next sub-section for the other industry-level competition measures). We also collected management practices data in the survey. These were scored following the methodology of Bloom and Van Reenen (2007), with practices grouped into four areas: operations (three practices), monitoring (five practices), targets (five practices) and incentives (five practices). The shop-floor operations section focuses on the introduction of lean manufacturing techniques, the documentation of processes improvements and the rationale behind introductions of improvements. The monitoring section focuses on the tracking of performance of individuals, reviewing performance, and consequence management. The targets section examines the type of targets, the realism of the targets, the transparency of targets and the range and interconnection of targets. Finally, the incentives section includes promotion criteria, pay and bonuses, and fixing or firing bad performers, where best practice is deemed the approach that gives strong rewards for those with both ability and effort. Our management measure uses the unweighted average of the z-scores of all 18 dimensions.

\section{A.3 Industries and Industry level data}

Our basic industry code is the U.S. SIC (1997) three digit level - which is our common industry definition in all countries. We allocate each firm to its main three digit sector (based on sales). For the 3,601 firms in the sample we have 134 unique three-digit industries. There are at least ten sampled firms in each industry for $96.9 \%$ of the sample.

The "Lerner index of competition" constructed, as in Aghion et al. (2005), as the mean of (1 profit/sales) in the entire database (excluding the surveyed firms themselves) for every country 
industry pair. Profits are defined as EBIT (earning before interest and taxation) to include the costs of labor, materials and capital but exclude any financing or tax costs. The five year period 2000 to 2004 is used in every country to ensure comparability across countries (since earlier data is not available in Oriana). In the US and India private firms do not provide profits data so the index was constructed from the population of all publicly listed firms, obtained from Compustat for the US and the CMIE Prowess dataset for India.

\section{A.4 Regional and National Data}

\section{Trust: the World Values Survey}

The regional trust and religion variables have been calculated from the World Values Survey (WVS). The WVS is a cross-country project coordinated by the Institute for Social Research of the University of Michigan, under the direction of Ronald Inglehart. Each wave carries out representative surveys of the basic values and beliefs of individuals in a large cross-section of countries. The questionnaire contains answers to specific questions about religion and social attitudes, including several question on generalized and specific trust (e.g. trust in the family, government etc.), as well as detailed information on the social and education background of the respondents (age, income, education). The key question we use is the standard one: "Generally speaking, would you say that most people can be trusted or that you can't be too careful in dealing with people?"

The WVS data can be downloaded freely from the WVS website (www.worldvaluessurvey.org). For the purposes of our analysis, we use only individual entries with information on the respondent' region of residence. We pool together data relative to four successive waves of data collection (1981-1984, 1989-1993, 1994-1999 and 1999-2004. We use the WVS for all countries with the exception of Greece, for which the regional breakdown provided by the WVS is poor. Luckily, we can build regional aggregates of trust and religion using the European Social Survey (ESS, http://www.europeansocialsurvey.org), a biennial multi-country survey covering over 30 European nations, and including questions on trust and religion. The wording of the trust question is identical to the one used by the WVS, although the answers are coded on a scale from 1 to 10 , instead of the discrete 0/1 choices adopted by the WVS. To ensure comparability between countries, we convert into 1s all the answers greater than 5 . The first round of the ESS was fielded in 2002/2003, the second in 2004/2005 and the third in 2006/2007. We pool across all waves of the ESS. The frequencies by country and wave are shown in Table A8.

\section{European Commission Bilateral Trust Data}

This comes directly from Table 1; panel B of Guiso et al. (2009). They averaged over multiple waves of a Eurobarometer survey carried out for the European Commission from the 1970s onwards. The question is: "I would like to ask you a question about how much trust you have in people from various countries. For each, please tell me whether you have a lot of trust, some trust, not very much trust, or no trust at all.” This was asked to all European Union Member States about each other and a number of other countries (including the US, China and Japan). We allocated the bilateral trust measure across the multinational subsidiaries included in our sample using information on the country where the parent company is headquartered and on the country where the subsidiary itself is located. So, for example, the measure of bilateral trust reported by Swedish 
people towards Italians would be allocated to the subsidiary of a Swedish multinational located in Italy.

\section{Regional Firm Size and Share of Manufacturing Employment}

Average regional firm size and the industry share of employment in each region by SIC2 were computed using employment data on the population of all public and private firms included in the BVD and CMIE accounting databases described above. The data refers mostly to 2006 (earlier years of the accounting data have been used whenever 2006 was not available, as long as the firm appeared to be still active). Since the accounting databases did not always provide information on the region of location of the firm, each firm was allocated to a region or state according to the headquarter postcode whenever this was available. If the postcode was not available, information on the city of location was used to map the firm into a specific region or state. With this procedure, we obtained regional information for virtually all firms included in the databases.

\section{GDP per Capita and Population}

The regional GDP per capita and population variables are drawn from the following sources: Europe: Eurostat, Regional Statistics ${ }^{57}$; United States: Bureau of Economic Analysis, regional Statistics ${ }^{58}$; Japan: Japan Statistic Bureau, Prefectural Statistics ${ }^{59}$; China: Province data from Chinadataonline.org ${ }^{60}$; India: State level data from the Central Statistical Organisation (CSO) ${ }^{61}$. The data refers to 2006 and is expressed in national currencies (country dummies are included in all regressions).

\section{Rule of Law}

The Rule of Law variable measures the extent to which agents have confidence in and abide by the rules of society, and in particular the quality of contract enforcement, the police, and the courts, as well as the likelihood of crime and violence. The index is compiled by the World Bank (Kauffman et al, 2007), and ranges between -2.5 and 2.5. The data can be downloaded from: http://info.worldbank.org/governance/wgi2007/resources.htm

\section{Bilateral-trust instrumental variables:}

Somatic distance: This is obtained using the data from Guiso et al (2009) for most of our Europeans countries, and their methodology to extend to the rest of Europe, China and the US. Quoting from their paper:

"We derive an indicator of somatic distance, based on the average frequency of specific traits in the indigenous population reported in Biasutti (1954). For height, hair color (pigmentation), and cephalic index (the ratio of the length and width of the skull), Biasutti (1954) draws a map of the prevailing traits in each country in Europe. For each trait, European Union countries fall into three different categories. For hair color we have "Blond prevails," "Mix of blond and dark," and "Dark prevails." We arbitrarily assign the score of 1 to the first, 2 to the second and 3 to the third. When one's country somatic characteristics belong to more than one category, we take the country's most prevalent

\footnotetext{
${ }^{57}$ http://epp.eurostat.ec.europa.eu/portal/page?_pageid=0,1136162,0 45572076\&_dad=portal\&_schema=PORTAL

${ }^{58}$ http://www.bea.gov/regional/gsp/

59 http://www.stat.go.jp

${ }^{60} \mathrm{http://chinadataonline}$. org $/$ member/macroyr/macroyrtshow.asp?code=A0101

61 http://mospi.nic.in/cso_test1.htm
} 
category. We then compute the somatic distance between two countries as the sum of the absolute value of the difference in each of these traits"

We extend this be collecting data for China and Poland from Biasutti (1957), assuming Luxembourg has the average values for France and Germany, and the US has the values of its European immigrants, weighted by their ancestry shares reported in 1999 US Census. We use only European immigrants because they appear to overwhelming be the owners and managers of the types of medium sized manufacturing firms in our survey.

Religious distance: Again, this is obtained from Guiso et al (2009) for most of our European countries, and their methodology to extend to the rest of Europe, China and the US. Quoting from their paper:

"The first proxy for culture is an indicator of religious similarity equal to the empirical probability that two randomly chosen individuals in two countries will share the same religion. We obtain this measure by taking the product of the fraction of individuals in country $j$ and in country $i$ who have religion $k$ and then we sum across all religions $k(k=$ Catholic, Protestant, Jewish, Muslim, Hindu, Buddhist, Orthodox, no-religion, other affiliation). To calculate this variable we use the percentage of people belonging to each religious denomination from the World Values Survey"

We extend this to all other necessary country-pairs using the World Values Survey. 


\section{APPENDIX TABLE A1}

\section{DETAILS OF THE DECENTRALIZATION SURVEY QUESTIONS}

The electronic survey, training materials and survey video footage are available on http://cep.lse.ac.uk/management/default.asp

For Questions D1, D3 and D4 any score can be given, but the scoring guide is only provided for scores of 1, 3 and 5.

Question D1: “To hire a FULL-TIME PERMANENT SHOPFLOOR worker what agreement would your plant need from CHQ (Central Head Quarters)?”

Probe until you can accurately score the question - for example if they say "It is my decision, but I need sign-off from corporate HQ." ask "How often would sign-off be given?"

Scoring grid: No authority - even for replacement

$$
\text { Score } 1
$$

Score 3

Score 5 hires

Requires sign-off from CHQ based on the business case. Typically agreed

(i.e. about $80 \%$ or $90 \%$ of the time).

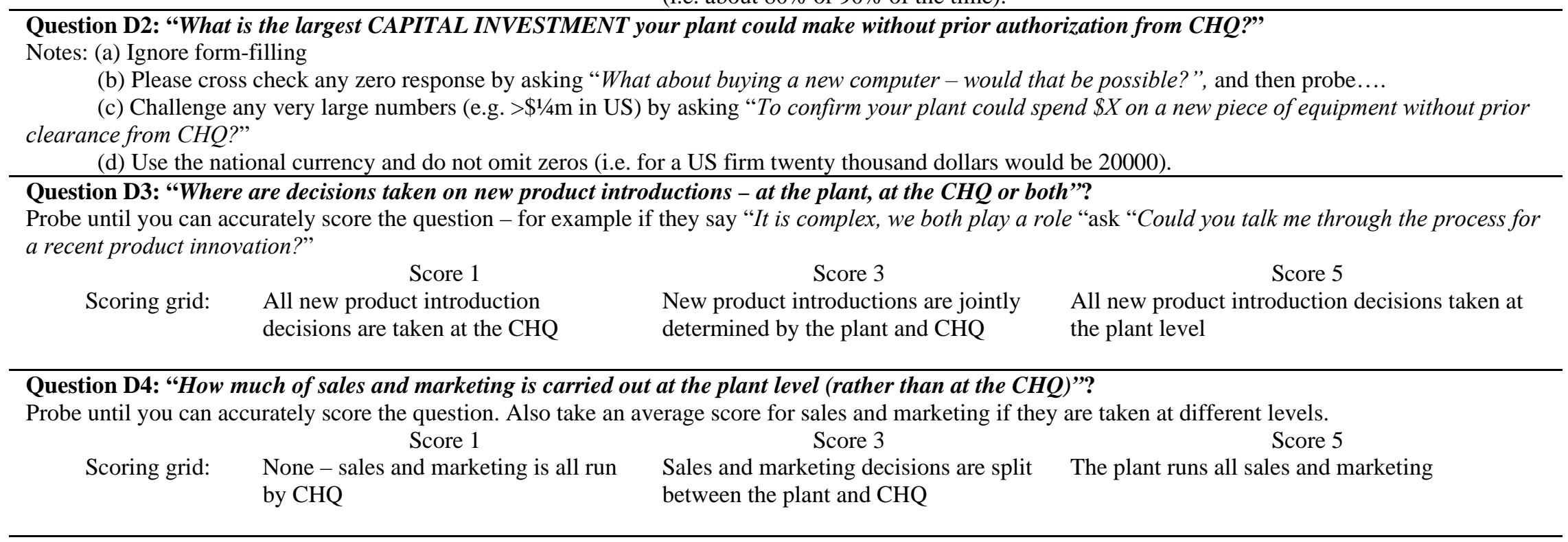

Question D5: "Is the CHQ on the site being interviewed"? 
TABLE A2

DECENTRALIZATION: INDIVIDUAL COMPONENTS BY COUNTRY

\begin{tabular}{|c|c|c|c|c|}
\hline & $\begin{array}{c}\text { Hiring } \\
\text { (1 to 5) } \\
(1) \\
\end{array}$ & $\begin{array}{c}\begin{array}{c}\text { Marketing } \\
\text { (1 to 5) }\end{array} \\
(2) \\
\end{array}$ & $\begin{array}{c}\text { Product Introduction } \\
\text { (1 to 5) } \\
(3) \\
\end{array}$ & $\begin{array}{c}\text { Investment (Median, in \$) } \\
\text { (4) } \\
\end{array}$ \\
\hline China & 3.20 & 1.43 & 1.75 & 604 \\
\hline France & 2.80 & 1.98 & 2.21 & 9,375 \\
\hline Germany & 2.93 & 2.17 & 2.57 & 12,500 \\
\hline Greece & 2.44 & 1.39 & 1.80 & 1,250 \\
\hline India & 2.77 & 1.79 & 2.16 & 220 \\
\hline Italy & 2.84 & 1.93 & 2.38 & 6,250 \\
\hline Japan & 1.96 & 1.70 & 1.91 & 1,720 \\
\hline Poland & 2.86 & 2.04 & 2.30 & 310 \\
\hline Portugal & 3.03 & 1.76 & 2.37 & 3,125 \\
\hline Sweden & 3.57 & 2.47 & 2.83 & 13,800 \\
\hline UK & 3.46 & 2.53 & 2.53 & 9,150 \\
\hline US & 3.86 & 2.17 & 2.58 & 7,500 \\
\hline
\end{tabular}

Notes: Averages of the individual components of the decentralization variable by country $(\mathrm{N}=3,380)$ 
TABLE A3

THE SURVEY SAMPLE DESCRIPTIVE STATISTICS

\begin{tabular}{|c|c|c|c|c|c|c|c|c|c|c|c|c|c|c|}
\hline & All & $\mathbf{C N}$ & FR & GE & GR & IN & IT & JP & PO & PT & SW & UK & US & $\begin{array}{c}\text { Missing, } \\
\text { \# }\end{array}$ \\
\hline Observations, \# & 4,038 & 325 & 323 & 348 & 187 & 470 & 204 & 122 & 239 & 177 & 286 & 649 & 694 & $\mathrm{n} / \mathrm{a}$ \\
\hline Firms, \# & 3,902 & 319 & 313 & 308 & 187 & 467 & 207 & 121 & 239 & 177 & 259 & 609 & 682 & $\mathrm{n} / \mathrm{a}$ \\
\hline $\begin{array}{l}\text { Firms, excluding } \\
2004 \text { resurvey, \# }\end{array}$ & & & 242 & 225 & & & & & & & & 560 & 535 & $\mathrm{n} / \mathrm{a}$ \\
\hline $\begin{array}{l}\text { Firm employees } \\
\text { (median) }\end{array}$ & 270 & 700 & 240 & 500 & 230 & 250 & 185 & 310 & 250 & 183 & 267 & 250 & 375 & 0 \\
\hline $\begin{array}{l}\text { Firm employees excl. } \\
2004 \text { resurvey }\end{array}$ & & & 200 & 325 & & & & & & & & 250 & 300 & $\mathrm{n} / \mathrm{a}$ \\
\hline $\begin{array}{l}\text { Plant employees } \\
\text { (median) }\end{array}$ & 150 & 500 & 150 & 225 & 120 & 150 & 150 & 150 & 150 & 125 & 150 & 140 & 150 & 0 \\
\hline $\begin{array}{l}\text { Production sites } \\
\text { (median), \# }\end{array}$ & 2 & 1 & 3 & 2 & 1 & 1 & 2 & 2 & 1 & 1 & 2 & 2 & 3 & 94 \\
\hline $\begin{array}{l}\text { Age of firm } \\
\text { (median, years) }\end{array}$ & 34 & 12 & 39 & 40 & 32 & 22 & 33 & 57 & 31 & 35 & 62 & 34 & 33 & 101 \\
\hline Listed firm, \% & 14.5 & 6.4 & 4.6 & 16.4 & 18.7 & 26.2 & 1.4 & 28.3 & 2.3 & 5.6 & 1.7 & 6.5 & 30.1 & 121 \\
\hline $\begin{array}{l}\text { Share of workforce } \\
\text { with degrees } \%\end{array}$ & 17.3 & 8 & 17.3 & 14.9 & 11.9 & 22 & 16.3 & 30.9 & 20 & 9.6 & 19.8 & 12.9 & 20.1 & 436 \\
\hline Management (mean) & 2.99 & 2.61 & 2.99 & 3.18 & 2.64 & 2.54 & 3 & 3.15 & 2.88 & 2.73 & 3.15 & 3 & 3.31 & 0 \\
\hline Trust, \% & 38 & 65 & 17 & 33 & 15 & 39 & 40 & 43 & 31 & 16 & 72 & 36 & 42 & 48 \\
\hline 1-Lerner index & 0.957 & 0.95 & 0.965 & 0.949 & 0.935 & 0.923 & 0.965 & 0.966 & 0.967 & 0.972 & 0.98 & 0.968 & 0.94 & 111 \\
\hline $\begin{array}{l}\text { Foreign } \\
\text { multinationals, \% }\end{array}$ & 0.25 & 0.2 & 0.46 & 0.31 & 0.19 & 0.1 & 0.25 & 0.03 & 0.35 & 0.18 & 0.44 & 0.38 & 0.14 & 0 \\
\hline $\begin{array}{l}\text { Domestic } \\
\text { multinationals, \% }\end{array}$ & 0.22 & 0.01 & 0.34 & 0.36 & 0.13 & 0.02 & 0.22 & 0.32 & 0.04 & 0.2 & 0.39 & 0.25 & 0.33 & 0 \\
\hline $\begin{array}{l}\text { Interview duration } \\
\text { (minutes) }\end{array}$ & 47.9 & 48.6 & 46.3 & 44.7 & 49.8 & 59.8 & 46.6 & 58.4 & 47.8 & 54.5 & 56.3 & 43.5 & 46.8 & 34 \\
\hline Trust & 0.39 & 0.54 & 0.21 & 0.35 & 0.23 & 0.39 & 0.38 & 0.42 & 0.26 & 0.16 & 0.66 & 0.34 & 0.43 & 0 \\
\hline Hierarchy & 0.34 & 0.01 & 0.56 & 0.38 & 0.91 & 0.11 & 0.79 & 0.03 & 0.94 & 0.82 & 0.01 & 0.18 & 0.27 & 395 \\
\hline $\begin{array}{l}\text { GDP per capita (in } \\
2006 \text { US\$) }\end{array}$ & 29,380 & 333 & 39,525 & 40,132 & 20,871 & 356 & 35,812 & 24,695 & 7,987 & 20,926 & 45,977 & 49,864 & 89,968 & 23 \\
\hline Regional Pop ('000) & 41,468 & 161.445 & 8,077 & 10,072 & 2,325 & 66,085 & 12,744 & 27,369 & 6,663 & 2,892 & 1,284 & 8,467 & 34,603 & 23 \\
\hline
\end{tabular}


TABLE A4

THE 2006 SAMPLING FRAME

\begin{tabular}{|c|c|c|c|c|c|c|c|c|c|c|c|c|c|}
\hline & $\mathbf{C N}$ & FR & GE & GR & IN & IT & $\mathbf{J P}$ & PO & PT & SW & UK & US & All \\
\hline $\begin{array}{l}\text { Sampling frame, } \\
\text { number of firms (\#) }\end{array}$ & 86,733 & 4,683 & 9,722 & 522 & 31,699 & 5,182 & 3,546 & 3,684 & 1,687 & 1,034 & 5,953 & 27,795 & 15,187 \\
\hline $\begin{array}{l}\text { Employees (median, } \\
\text { sampling frame) }\end{array}$ & 290 & 201 & 198 & 180 & 175 & 183 & 240 & 200 & 127 & 206 & 219 & 200 & 202 \\
\hline $\begin{array}{l}\text { Employees (median, } \\
\text { conditioning on firms } \\
\text { with } 150+\text { employees) }\end{array}$ & 290 & 291 & 285 & 269 & 229 & 262 & 240 & 260 & 239 & 315 & 311 & 300 & 274 \\
\hline Publicly listed (\%) & 1 & 4 & 1 & 17 & 11 & 1 & 1 & 3 & 1 & 6 & 4 & 4 & 4 \\
\hline
\end{tabular}

Notes: CN=China, FR=France, GE=Germany, GR=Greece, IN=India, IT=Italy, JP=Japan, PO=Poland, PT=Portugal, SW=Sweden, UK=United Kingdom, US=United States. Sampling frame is the total number of eligible firms for the survey. The sampling frame includes all firms between 100 and 5,000 employees in the population accounting databases for all countries, excluding China and Japan (for which the employment bracket is 150 to 5,000 employees) and Portugal (for which the employment bracket is 75 to 5,000 employees). Employees are the median number of employees in the firm. Publicly listed is the percentage of firms which are directly publicly listed (note that some firms may be privately incorporate subsidiaries of publicly listed parents). Indian and Japanese employment numbers are predicted from balance sheet information for privately held firms (India) and unconsolidated accounts (Japan). 
TABLE A5

THE COVERAGE OF THE FIRM ACCOUNTING DATABASES

\begin{tabular}{|c|c|c|c|c|c|c|c|c|c|c|c|c|}
\hline & CN & FR & GE & GR & IN & IT & $\mathbf{J P}$ & PO & PT & SW & UK & US \\
\hline $\begin{array}{l}\text { Employees in firms in accounting databases with } 50+ \\
\text { employees, 000's }\end{array}$ & 56,742 & 2,223 & 6,453 & 153 & 6,773 & 1,754 & 9,214 & 1,224 & 380 & 331 & 2,188 & 15,150 \\
\hline $\begin{array}{l}\text { Employees in firms with } 50+\text { employees in the } \\
\text { accounting databases as \% of Census data }\end{array}$ & $84 \%$ & $89 \%$ & $117 \%$ & $92 \%$ & $103 \%$ & $89 \%$ & $137 \%$ & $72 \%$ & $96 \%$ & $62 \%$ & $100 \%$ & $135 \%$ \\
\hline Sample median year & 2007 & 2006 & 2006 & 2006 & 2004 & 2006 & 2007 & 2006 & 2006 & 2006 & 2006 & 2007 \\
\hline Census year & 2004 & 2006 & 2006 & 2006 & 2005 & 2006 & 2006 & 2006 & 2006 & 2006 & 2006 & 2006 \\
\hline
\end{tabular}

Notes: CN=China, FR=France, GE=Germany, GR=Greece, IN=India, IT=Italy, JP=Japan, PO=Poland, PT=Portugal, SW=Sweden, UK=United Kingdom, US=United States. This compares total employment in our accounting database (from which the sampling frame was drawn) that should cover the population of manufacturing firms with Census Bureau data (from mandatory government surveys). All census units are firms except India which is plant level. Employees in firms in the accounting databases with 50+ employees, 000's reports the number of employees in firms in the accounting databases with 50 or more employees (in thousands). Employees in firms with 50+ in the accounting databases as \% of Census data reports the share of employees in the accounting databases in firms with 50 or more employees as a proportion of the values reported in national Census data (except for the US, where we report the share of employees in firms with 20 or more employees as the 50 or more cut-off is not available). Census data is drawn from Eurostat Structural Business Statistics for the European countries, Bureau of the Census for the US, Statistics Bureau for Japan, Annual Survey of Industries for India, and Chinese Industrial Survey. For China and India, Census calculations done by Albert Bollard on data provided by Pete Klenow. Consolidated accounts are excluded from accounting data to avoid duplications. Eurostat defines an enterprise as the "smallest combination of legal units that is an organizational unit producing goods or services, which benefits from a certain degree of autonomy in decision-making, and an enterprise carries out one or more activities at one or more locations”. The Bureau of the Census defines an enterprise as "a business organization consisting of one or more domestic establishments under common ownership or control". The Statistics Bureau of Japan defines an enterprise as "an entity composed of the head office and branch establishments, if any, whose legal organization is a stock company, limited company, limited or unlimited partnership, limited liability company, or mutual insurance company”. In the Indian Annual Survey of Industries a factory "refers to any whereon ten or more workers are working, or were working on any day of the preceding twelve months, and in any part of which a manufacturing process is being carried on with the aid of power, or is ordinarily so carried on, or whereon twenty or more workers are working or were working on any day of the preceding twelve months, and in any part of which a manufacturing process is being carried on without the aid of power, or is ordinarily so carried on". In the Chinese Industrial Survey "industrial establishments refer to economic units which are located in one single place and engage entirely or primarily in one kind of industrial activity, including financially independent industrial enterprises and units engaged in industrial activities under the non industrial enterprises (or financially dependent). Industrial establishments generally meet the following requirements: They have each one location and are engaged in one kind of industrial activity each; they operate and manage their industrial production activities separately; they have accounts of income and expenditures separately.” 
TABLE A6: THE SURVEY RESPONSE RATE

\begin{tabular}{lccccccccccccc}
\hline \hline & All & CN & FR & GE & GR & IN & IT & JP & PO & PT & SW & UK & US \\
$\begin{array}{l}\text { Interviews } \\
\text { completed (\%) }\end{array}$ & 44.9 & 43.9 & 59.3 & 58.6 & 53.4 & 61.4 & 68.2 & 21.5 & 37.5 & 60.5 & 68.2 & 32.9 & 37.2 \\
$\begin{array}{l}\text { Interviews refused } \\
\text { (\%) }\end{array}$ & 16.8 & 13.7 & 13.7 & 27.2 & 10.7 & 13.7 & 20.0 & 20.1 & 16.5 & 15.8 & 16.9 & 19.6 & 13.7 \\
$\begin{array}{l}\text { Scheduling in } \\
\text { progress (\%) }\end{array}$ & 38.3 & 40.1 & 27.0 & 14.2 & 35.9 & 25.0 & 11.8 & 58.4 & 46.0 & 23.7 & 14.9 & 47.4 & 49.1 \\
$\begin{array}{l}\text { Survey sample, } \\
\text { number firms (\#) }\end{array}$ & 8,690 & 727 & 528 & 526 & 350 & 761 & 304 & 563 & 637 & 293 & 380 & 1,851 & 1,833 \\
$\begin{array}{l}\text { Interviews } \\
\text { completed (\#) }\end{array}$ & 3,902 & 319 & 313 & 308 & 187 & 467 & 207 & 121 & 239 & 177 & 259 & 609 & 682 \\
\hline \hline
\end{tabular}

Notes: All=All countries combined, $\mathrm{CN}=$ China, FR=France, GE=Germany, GR=Greece, IN=India, IT=Italy, JP=Japan, PO=Poland, $\mathrm{PT}=$ Portugal, SW=Sweden, UK=United Kingdom, US=United States. Interviews completed reports the percentage of companies contacted for which a management interview was completed. Interviews refused reports the percentage of companies contacted in which the manager contacted refused to take part in the interview. Scheduling in progress reports the percentage of companies contacted for which the scheduling was still in progress at the end of the survey period (so the firm had been contacted, with no interview run nor any manager refusing to be interviewed). Survey sample is the total number of firms that were randomly selected from the complete sampling frame. 
TABLE A7

RESPONSE RATES TO THE SURVEY

(1)

(2)
Sample

Log (Sales/employee)

Return on Capital Employed (ROCE) $)^{\S}$

Trust (region) $)^{\S \S}$

Hierarchical (region) ${ }^{\S \S}$

Log (employment)

Listed

Log (Age of firm), in years

Multinational subsidiary

Days from the start of the survey until firm contacted ${ }^{\S}$

Country is China

Country is France

Country is Germany

Country is Greece

Country is India

Country is Italy

Country is Japan

Country is Poland

Country is Portugal

Country is Sweden

Country is UK
All firms contacted

0.029

(0.031)

$-0.22$

(0.457)

$-0.356$

(0.266)

$0.099 * * *$

(0.025)

$-0.042$

(0.075)

0.021

(0.028)

$0.118^{* *}$

(0.051)

$-0.087 * * *$

(0.023)

$-1.465 * * *$

(0.444)

$0.886 * * *$

(0.219)

$0.902 * * *$

(0.171)

$0.512 *$

(0.275)

$0.583^{* * *}$

(0.218)

$0.955 * * *$

(0.276)

$-0.123$

(0.207)

$0.726 * *$

(0.286)

$0.905 * *$

(0.369)

$0.929 * * *$

(0.236)

0.114

(0.105)

Baseline
All firms contacted

0.025

(0.043)

0.310

(0.580)

$-0.301$

(0.423)

$0.073^{* *}$

(0.031)

0.060

(0.106)

0.029

(0.034)

$0.125^{* *}$

(0.056)

$-0.101 * *$

(0.041)

$\mathrm{n} / \mathrm{a}$

$0.837^{* * * *}$

(0.247)

$1.109 * * *$

(0.216)

0.468

(0.382)

$\mathrm{n} / \mathrm{a}$

$0.859 * *$

(0.359)

$\mathrm{n} / \mathrm{a}$

0.470

(0.402)

$1.016^{* *}$

(0.445)

$0.597 * *$

(0.256)

Baseline

Country is US

0.162

$\mathrm{n} / \mathrm{a}$

6,679

0.138

4,308

Number of firms

6,679

Notes: The dependent variable is a dummy for a completed interview. All columns estimated by probit with robust standard errors in parentheses (marginal effects reported). All columns include a full set of 44 interviewer dummies, and 142 three digit industry dummies. The dependent variable takes value one if the firm was interviewed, and zero if the interview was refused, or if scheduling was still in progress as the end of the project. In column (2) firms are dropped if Return on Capital Employed data is available. § Coefficient and standard-errors multiplied by 100 . $\S \S$ Refers to region where the company is headquartered. Regressions weighted by the share of World Values Survey respondents in the region in the country. 
TABLE A8

WORLD VALUES SURVEY SAMPLE

\begin{tabular}{lccccc}
\hline \hline WVS Wave & $\mathbf{1 9 8 1 - 1 9 8 4}$ & $\mathbf{1 9 8 9 - 1 9 9 3}$ & $\mathbf{1 9 9 4 - 1 9 9 9}$ & $\mathbf{1 9 9 9 - 2 0 0 4}$ & Total \\
China & 0 & 983 & 1,064 & 0 & 2,047 \\
France & 0 & 939 & 0 & 1,560 & 2,499 \\
Germany & 1,084 & 2,893 & 1,956 & 1,937 & 7,870 \\
Greece & 0 & 0 & 0 & 4.972 & 4.972 \\
India & 0 & 2,365 & 1,769 & 1,898 & 6,032 \\
Italy & 0 & 1,931 & 0 & 1,946 & 3,877 \\
Japan & 1,099 & 911 & 990 & 1,254 & 4,254 \\
Poland & 0 & 1,709 & 0 & 1,059 & 2,768 \\
Portugal & 0 & 1,149 & 0 & 975 & 2,124 \\
Sweden & 0 & 944 & 0 & 974 & 1,918 \\
United Kingdom & 0 & 1,440 & 1,073 & 921 & 3,434 \\
United States & 0 & 1,764 & 1,458 & 1,188 & 4,410 \\
\hline & & & & \\
Total & 2,183 & 17,028 & 8,310 & 13,712 & 41,233 \\
\hline \hline
\end{tabular}

Notes: Number of respondents used to build regional trust and religion aggregates by country and World Values Survey wave. Data relative to Greece are built from the ESS, using all available waves between 2000 and 2005. 